\title{
Article
}

\section{Regulating Financial Change: A Functional Approach}

\section{Steven L. Schwarcz ${ }^{\dagger}$}

\section{INTRODUCTION}

Most regulatory reform after the 2008-09 global financial crisis (the financial crisis) represents politically motivated reactions to that crisis, often looking for wrongdoers (whether or not they exist) or focusing on subprime-related mortgage problems associated with the crisis. ${ }^{1}$ The Dodd-Frank Act, ${ }^{2}$ for ex-

$\dagger \quad$ Stanley A. Star Professor of Law \& Business, Duke University School of Law; Founding Director, Duke Global Financial Markets Center; Senior Fellow, the Centre for International Governance Innovation. E-mail: schwarcz@law.duke.edu. For valuable comments, I thank John Armour, Daniel Awrey, Colleen M. Baker, Stephen F. Diamond, Robert C. Hockett, Charles Klingman, Katharina Pistor, Karen West, Eugene N. White, Elizabeth Woodman, and participants at a faculty workshop at Stanford Law School; a public lecture at the London School of Economics and Political Science; a conference on international financial regulation at Chatham House, London (sponsored by the University of Glasgow); a public lecture at the University of California Berkeley School of Law (sponsored by its Center for Law, Business, and the Economy); a roundtable on financial regulation at Queen Mary, University of London (sponsored by its Centre for Commercial Law Studies); a conference on bank regulation at Ludwig-Maximilians-Universitat Munchen (sponsored by its Center for Advanced Studies); and a conference on financial system design at the University of Toronto Faculty of Law. I also thank Lorna Knick, Eric Pacifici, and Jonathan Rash for excellent research assistance. Support is provided in part by a gift to Duke Law School from the Eugene T. Bost, Jr. Research Professorship of the Cannon Charitable Trust No. 3 and by a grant from the International Insolvency Institute Foundation. Copyright @ 2016 by Steven L. Schwarcz.

1. Cf. infra notes 28-32 and accompanying text (discussing other reasons why regulatory reforms after a financial crisis tend to be misguided).

2. The Dodd-Frank Act delegates much of the regulatory details to administrative rulemaking, in many cases after the relevant government agencies engage in further study. Perhaps even more significantly, the Act creates a Financial Stability Oversight Council, part of whose mission is to monitor and identify potential systemic threats in order to find regulatory gaps. DoddFrank Act $\S 112$, 12 U.S.C. $\S 5322$ (2012). The Council is aided in this task by a newly-created Office of Financial Research. Id. Regulators therefore will 
ample, puts much weight on reforming mortgage financing. Because the financial system is constantly changing, however, future financial crises are unlikely to resemble, and may have very different causes than, past crises.

This raises the broader question: How should we think about regulating a dynamically changing financial system? ${ }^{3}$ Even otherwise salutary financial regulation is often tethered to the financial architecture-the particular design and structure of financial firms, markets, and other related institutions-at the time the regulation is promulgated. ${ }^{4}$ That type of

have the ability to look beyond the Act's confines.

3. This Article takes financial change as a given, especially in light of the advent of the shadow-banking system. See infra note 10 and accompanying text (discussing shadow banking). The Article's normative analysis therefore relies to some extent on the nature of reality. $C f$. ISAIAH BERLIN, PERSONAL IMPRESSIONS xxi (Henry Hardy ed., 2001) (arguing that norms are and should be factually based and tethered to reality); Lucian Arye Bebchuk, A New Approach to Corporate Reorganizations, 101 HARV. L. REV. 775, 776-77 (1988) (grafting a normative analysis onto a positive assumption, in that case taking the existence of corporate reorganizations in bankruptcy law as a given to put forth a suggestion to improve the reorganization process). The Article does not attempt to judge the merits of financial change per se. Compare Robert C. Merton \& Zvi Bodie, A Conceptual Framework for Analyzing the Financial Environment, in THE GLOBAL FINANCIAL SYSTEM: A FUNCTIONAL PERSPECTIVE 3, 4 (Dwight B. Crane et al. eds., 1995) (viewing "financial innovation as driving the financial system toward the goal of greater economic efficiency"), with Steven L. Schwarcz, Framing Address: A Framework for Analyzing Financial Market Transformation, 36 SEATTLE U. L. REV. 299, 305 (2013) ("Shadow banking ... has the potential to create both benefit and harm. Empirically, we do not yet know which effect is likely to dominate."), and Emilios Avgouleas, Regulating Financial Innovation, in OXFORD HANDBOOK ON FINANCIAL REGULATION 659, 664 (Niamh Moloney et al. eds., 2015) ("In the past thirty years we have borne witness to a marked shift in the goals of financial innovations away from serving the real economy, as most innovations have done until the 1980 s, towards uncontrollable rent-seeking aided by ever more self-referential innovations, serving fictitious or artificial economic ends.") (footnotes omitted)).

4. The Dodd-Frank Act, for example, focuses heavily on the complex mortgage-backed securities and derivatives that are believed to have been triggers of the financial crisis. The Glass-Steagall Act limited the ability of commercial banks to engage in securities underwriting, which was thought to have "fueled the rampant stock speculation preceding the 1929 Crash and contributed to subsequent bank failures." Don More, Note, The Virtues of GlassSteagall: An Argument Against Legislative Repeal, 1991 CoLUM. BUS. L. REV. 433, 436. The Federal Reserve's Regulations G, U, T, and X limited margin lending (lending to enable borrowers to purchase publicly traded stock, with the loans secured by the purchased stock), in response to concerns that such lending similarly encouraged stock speculation. $C f$. Lynn A. Stout, Why the Law Hates Speculators: Regulation and Private Ordering in the Market for OTC Derivatives, 48 DUKE L.J. 701, 730 (1999). And the Commodity Exchange Act responded to complaints "that futures traders were manipulating and 'fix- 
grounded regulation has value as long as it is updated as needed to adapt to changes in the financial architecture. ${ }^{5}$ This helps to explain the success of the Uniform Commercial Code (UCC) in the United States, a model uniform-state-law statute that is essentially apolitical, ${ }^{6}$ which benefits from ongoing monitoring and updating by the non-partisan American Law Institute and the Uniform Law Commission. ${ }^{7}$

Ongoing monitoring and updating can be costly, however, and is subject to political interference at each updating stage. In the United States, where financial regulation is primarily the province of federal law and highly politically charged, it currently does not appear feasible given the dysfunctional U.S. Congress. ${ }^{8}$ Yet without ongoing monitoring and updating, financial regulation tethered to today's financial architecture will quickly become outmoded, causing unanticipated consequences and allowing innovations to escape regulatory scrutiny. This occurred in 2008, for example, when the pre-crisis financial regulatory framework, which assumed the dominance

ing' market prices." Lynn A. Stout, Derivatives and the Legal Origin of the 2008 Credit Crisis, 1 HARV. BUS. L. REV. 1, 17 (2011) [hereinafter Stout, Derivatives].

5. $C f$. Perry Mehrling, The New Lombard Street: How the Fed BeCAME THE DEALER OF LAST RESORT 4-5 (2011) (arguing that because economics and finance "largely ignore the sophisticated mechanism that operates to channel cash flows . . . to meet cash commitments," they have not "been particularly well suited for understanding the [financial crisis] during which the crucial monetary plumbing broke down").

6. Commercial law is apolitical because parties to commercial transactions can be on either side, depending on the transaction.

7. The Uniform Law Commission's official name is The National Conference of Commissioners on Uniform State Laws (abbreviated NCCUSL). Even the UCC's principal drafter, Karl Llewellyn, recognized the risk of tying legal rules too closely to the existing commercial architectures. KARL N. LLEWELlYN, THE THEORY OF RULES 79 (Frederick Schauer ed., 2011) (observing that the "pace of an industrial civilization ... present[s] [legal systems with] new states of fact too rapidly for knowledge to keep up with them," which could "throw[] into doubt the significance of the very lines of classification on which the would-be precise rules have been made to rest"). At least in part for that reason, Llewellyn included in the UCC certain key terms-such as "good faith," "usage of trade," and "unconscionability"-that focus on the underlying functions of commercial law, in order to "provide safety valves to make the entire system more predictable." Curtis Nyquist, Llewellyn's Code As a Reflection of Legal Consciousness, 40 NEW ENG. L. REV. 419, 433 (2006).

8. One might ask why the UCC is successful, given the political dysfunction of many state legislatures. Perhaps one answer is that individual states have little competitive choice but to enact updating amendments proposed by the non-political American Law Institute and Uniform Law Commission; without such enactment, a state's commercial law would become outdated, thereby discouraging commercial transactions within the state. 
of bank-intermediated funding, failed to adequately address a collapsing financial system in which the majority of funding had become non-bank intermediated. ${ }^{9}$ Because this shift to nonbank intermediated funding (usually referred to as "shadow banking" ${ }^{\prime 10}$ ) is continuing, I will use it as an example throughout this Article.

In thinking about regulating a dynamically changing financial system, it may be more effective-or at least instructive- to focus on the system's underlying, and thus less timedependent, economic functions than to tie regulation to any specific financial architecture. ${ }^{11}$ When I was originally trained

9. Cf. Julia Black, Restructuring Global and EU Financial Regulation: Character, Capacities, and Learning, in FINANCIAL REGULATION AND SUPERVISION: A POST-CRISIS ANALYSIS 3, 13 (Eddy Wymeersch, Klaus J. Hopt \& Guido Ferrarini, eds., 2012) ("[T] he system simply did not operate in the way that regulators, banks, and economists had thought it did. If you do not understand how the system works, it is very hard to build in mechanisms either for managing risk or for ensuring the system's resilience when those risks crystallize.").

10. Shadow banking is a loose term that refers to the increasing provision of financing outside of traditional banking channels, and thus without the need for traditional modes of bank intermediation between capital markets and the users of funds. See Steven L. Schwarcz, Regulating Shadow Banking, 31 REV. BANKING \& FIN. L. 619, 620 (2012). The size of the shadow banking sector-which includes securitization, money-market mutual funds, hedge funds, securities lending, asset-backed commercial paper (ABCP) conduits, structured investment vehicles (SIVs), and repo financing-was estimated at $\$ 60$ trillion worldwide in December 2011. See Philipp Halstrick, Tighter Bank Rules Give Fillip to Shadow Banks, REUTERS (Dec. 20, 2011, 4:17 AM), http://www.reuters.com/article/2011/12/20/uk-regulation-shadow-banking -idUSLNE7BJ00T20111220. More recent estimates suggest an even higher number. See Fin. STABILITY BD., GLOBAL SHADOW BANKING MONITORING REPORT 3 (2012), http://www.financialstabilityboard.org/publications/r 121118c.pdf (estimating shadow banking's worldwide assets as $\$ 67$ trillion in 2011); Sheridan Prasso, Shadow Banking, BloOMBERG (Mar. 31, 2015, 7:11 $\mathrm{AM}$ ), http://www.bloomberg.com/quicktake/shadow-banking (reporting that the Financial Stability Board believes that shadow banking grew by $\$ 5$ trillion $\$ 75$ trillion in 2013).

11. Cf. Iman Anabtawi \& Steven L. Schwarcz, Regulating Ex Post: How Law Can Address the Inevitability of Financial Failure, 92 TEX. L. REV. 75, 85 (2013) (observing that the difficulty with identifying the elements of the financial system by focusing on institutions, rather than functions, "is that it is unlikely to be adaptive when the system is experiencing change" (citing Wulf A. Kaal, Evolution of Law: Dynamic Regulation in a New Institutional Economics Framework 3-4 (Univ. of St. Thomas School of Law, Legal Studies Research Paper Series No. 13-17, 2013), http://papers.ssrn.com/sol3/papers.cfm? abstract_id=2267560 (describing the dynamic nature of financial regulation)). Professor Anabtawi and I argue for a more functional approach to macroprudential regulation, emphasizing the need for more ex post regulation of the financial system as a system. This approach should not be confused with 
as an aerospace engineer, we called this a "black-box" approach: examining the functionality of a process or application without worrying about the details of its internal structure. This facilitates the analysis of a highly complex or unknown structure. ${ }^{12}$ It also facilitates the analysis of a rapidly changing structure. The financial system epitomizes each.

Although unrelated to financial regulation, economists Robert Merton and Zvi Bodie likewise have recognized the utility of focusing on the underlying economic functions of the changing financial system. ${ }^{14}$ In order to try to understand how and why the institutional structure of the financial system changes and how it is likely to evolve, they view finance from a "functional perspective"-meaning that they focus on functions rather than on institutions. ${ }^{15}$ The rationale for their focus is similar to mine: that "[f]inancial functions are more stable than financial institutions-that is, functions change less over time." 16

A functional approach should also inform financial regulation. As will be shown, the principle underlying economic functions of the financial system are the provision, allocation, and deployment of capital. ${ }^{17}$ Regulation thus should operate to correct "market failures" that impair the ability of the components of the financial system-fundamentally, firms and markets-to provide these (and any related) functions. ${ }^{18}$ Economists refer to

the philosophical concept of "functionalism." See Functionalism, STANFORD ENCYCLOPEDIA OF PHILOSOPHY (July 3, 2013), http://plato.stanford.edu/ entries/functionalism/.

12. Cf. Kai Lyu, Post-Crisis Laws of Securitization in China: A Functional Perspective (Feb. 2015) (unpublished Ph.D. thesis, The Chinese University of Hong Kong) (on file with author) (taking a functional approach).

13. Focusing on functions rather than on particular financial architecture also helps to universalize the analysis across geographical and political borders. $C f$. Merton \& Bodie, supra note 3, at 4 (observing that functions "vary less across borders").

14. Merton shared the 1997 Nobel Prize in economics.

15. Merton \& Bodie, supra note 3.

16. Id. They similarly observe that although "[f]inancial activities . . are very old ... [t]he ways in which these activities are carried out . . . have changed through the ages." Id. at 6. Merton and Bodie also observe that a functional approach helps to better integrate financial regulation with neoclassical economics, which is "functional" insofar as what matters are prices and quantities, not the particular architecture of the institutions performing the functions. Id. at 10; see also id. at 10-11 (observing that neoclassical economics would view multiple ways of taking a levered position in the S\&P 500 stocks as equivalent).

17. See infra notes $43-45$ and accompanying text.

18. The primary purpose of financial regulation is to correct market fail- 
the regulation of components of the financial system as "microprudential" regulation. ${ }^{19}$ The traditional approach to microprudential regulation, however, is tied not to functional components but to components defined by the financial architecture. ${ }^{20}$ Part II of this Article conceptualizes a more functional approach to microprudential regulation. ${ }^{21}$

The other function of the financial system is to serve as a network within which the underlying economic functions can be conducted. ${ }^{22}$ Regulation should therefore also operate, as needed, to protect the financial system's ability to function as a network. ${ }^{23}$ Economists use the term "systemic risk" to refer to the risk that the financial system could fail to so function. ${ }^{24}$ They also use the term "macroprudential regulation" to refer to regulation designed to mitigate systemic risk. ${ }^{25}$ The traditional

ures. See infra note 49 and accompanying text.

19. Cf. Douglas J. Elliott, et al., The History of Cyclical Macroprudential Policy in the United States 6 (Fed. Reserve Bd., Finance and Economics Discussion Series No. 2013-29, 2013), http://www.federalreserve.gov/pubs/ feds/2013/201329/201329pap.pdf (observing that microprudential regulation is the "regulation of individual financial institutions"); Ben S. Bernanke, Chairman, Fred. Reserve Bd., Speech at the 47th Annual Conference on Bank Structure and Comeptition, Chicago, Ill.: Implementing a Macroprudential Approach to Supervision and Regulation 2 (May 5, 2011) (transcript available at http://www.federalreserve.gov/newsevents/speech/bernanke20110505a.pdf) ("The systemic orientation of the macroprudential approach may be contrasted with that of the traditional, or 'microprudential,' approach to regulation and supervision, which is concerned primarily with the safety and soundness of individual institutions, markets, or infrastructures.").

20. See supra note 4; see also Stout, Derivatives, supra note 4, at 17-18 (explaining how the Commodity Exchange Act focused on regulating the existing financial architecture in the over-the-counter derivatives market).

21. Professors Robert Merton and Zvi Bodie, in contrast, do not purport to tie functions to regulation. Rather, they use functions as a means of attempting to predict changes to the institutional structure of the financial system. See Merton \& Bodie, supra note 3.

22. See infra notes 146-47 and accompanying text.

23. See Anabtawi \& Schwarcz, supra note 11, at 90-91.

24. Cf. Steven L. Schwarcz, Systemic Risk, 97 GEO. L.J. 193, 204 (2008) [hereinafter Schwarcz, Systemic Risk] (defining "systemic" risk as the risk that a cascading failure of financial system components (e.g., markets or firms) undermines the system's ability to generate capital, or increases the cost of capital, thereby harming the real economy). Systemic risk represents risk to the financial system itself. Id. at 207-08.

25. See Robert Hockett, Implementing Macroprudential FinanceOversight Policy: Legal Considerations 4 (Jan. 20, 2013) (drafted for the International Monetary Fund, http://papers.ssrn.com/sol3/papers.cfm?abstract $\mathrm{id}=2340316$ (defining the term "macroprudential" as a "prefix [used] in finance-regulatory contexts, pertaining to the reduction of risks that imperil financial systems . . . as wholes"); see also Elliott et al., supra note 19 (observing 
approach to macroprudential regulation, however, is tied not to functional components but (as with the traditional approach to microprudential regulation) to components defined by the financial architecture. ${ }^{26}$ Part III of this Article conceptualizes a more functional approach to macroprudential regulation. ${ }^{27}$

My goal in conceptualizing these functional approaches is primarily normative. I am not claiming that functional regulation necessarily will, or even could, become politically viable. Policymakers and regulators tend to focus on the past, what economists have called "the powerful role of historical perception as a framing device." ${ }^{28}$ The opinions of European policymakers designing the European Union's monetary union, for example, were "heavily informed by past risks," notably the possibility that excessive budget deficits could spark high inflation (such as the German hyperinflation of the 1920s). ${ }^{29}$ As a result, EU policymakers ignored emerging problems, like the fact that Euro-area banks were even more highly leveraged than U.S. banks. ${ }^{30}$

Policymakers and regulators also respond to the media, which can create distortions by emphasizing what journalists find accessible. And even sophisticated journalists are sometimes imprecise and biased. ${ }^{31}$ Furthermore, after a financial crisis, people naturally want to prevent the next crisis. Regulators, who are themselves usually subject to political short-

that the goal of macroprudential regulation "is to manage factors that could endanger the financial system as a whole, even if they would not be obvious as serious threats when viewed in the context of any single institution").

26. See supra note 4; $c f$. Anabtawi \& Schwarcz, supra note 11 (referring to the traditional approach to macroprudential regulation, which is tied to components defined by the financial architecture, as an "institutional approach").

27. Professors Merton and Bodie tie their functional perspective to four "levels of analysis": system-level, institution-level, activity-level, and productlevel. Merton \& Bodie, supra note 3, at 16. But these levels appear to be subsumed within my macroprudential regulation analysis, which incorporates system-level analysis, and my microprudential regulation analysis, which incorporates the rest.

28. See, e.g., Barry Eichengreen, Euro Area Risk (Mis)management, in POLICY SHOCK: REGULATORY RESPONSES TO OIL SPILLS, NUClEAR ACCIDENTS, AND FINANCIAL MELTDOWNS 2 (Edward Balleisen et al. eds., forthcoming 2016) (draft on file with author).

29. Id. at 14 .

30. Id.

31. See Carrie Figdor, Is Objective News Possible?, in JOURNALISM ETHICS: A PHILOSOPHICAL APPROACH 160-62 (Christopher Meyers ed., 2010) (arguing that competing goals and the inadequacy of traditional journalistic practices undermine objectivity). 
termism, ${ }^{32}$ typically respond by focusing on ex ante preventative regulation, or at least regulation aimed at preventing the next financial meltdown. But that focus is insufficient because it is impossible to always predict the cause of the next financial crisis. Indeed, although panics are often the triggers that commence a chain of systemic failures, it is impossible even to identify all the causes of panics. ${ }^{33}$

Even if functional regulation could become politically viable, this Article does not suggest it should displace traditional regulation. Rather, it should serve as a set of ordering principles: a model with which real-world financial regulation could be compared. ${ }^{34}$ This is especially important because policymakers and regulators often take an ad hoc approach to regulation, generally viewing macroprudential regulatory measures as a loose assortment of "tools" in their "toolkit." Even the theoretical scholarship on law and finance takes a somewhat similar ad hoc approach, yielding "propositions [that] can serve as a tool kit" for regulatory scrutiny. ${ }^{36}$ A more normative framework could help to counter, or at least to place into perspective, po-

32. Politicians have short-term reelection goals whereas good regulatory solutions are often long-term. See, e.g., James C. Cooper \& William E. Kovacic, Behavioral Economics and Its Meaning for Antitrust Agency Decision Making, 8 J.L. ECON. \& POL'Y 779, 793 (2012) (“[R]egulators with short-term biasesboth due to high political weighting and bias-are likely to be over represented in the population of regulators."); $c f$. Donald Kohn, Senior Fellow, Brookings Inst., Speech at the Kennedy School of Government, Harvard University (Apr. 17, 2014) (transcript available at http://www.brookings.edu/research/ speeches/2014/04/17-institutions-macroprudential-regulation-kohn) (observing that effective financial regulation will require insulation from short-term political pressures).

33. See Steven L. Schwarcz, Controlling Financial Chaos: The Power and Limits of Law, 2012 Wis. L. REV. 815, 822.

34. See Lorenz Kahler, The Influence of Normative Reasons on the Formation of Legal Concepts, in CONCEPTS IN LAW 81, 90 (Jaap C. Hage \& Dietmar von der Pfordten eds., 2009) (citing D. Patterson, Dworkin on the Semantics of Legal and Political Concepts, 26 OxFORD J. LEG. STUDS. 552, 553 (2006)) (explaining how normative analysis benefits legal reasoning); Frederic R. Kellogg, Comparing Natural and Normative Inquiry: The "Real" and the "Right" as Ordering Concepts 7 (May 27, 2011) (unpublished manuscript), http://papers.ssrn.com/sol3/papers.cfm?abstract_id=1854464 (arguing that normative legal inquiry can create an ordering concept, binding the community and directly influencing action, with the goal of achieving coherence, consistency, and predictability).

35. See, e.g., Hockett, supra note 25, at 12-13 (discussing the "emergent macroprudential toolkit as currently constituted").

36. Daniel Awrey et al., An Overview of the Legal Theory of Finance 2 (2014) (unpublished manuscript) (on file with author). 
tential financial industry lobbying for only selective "tools." ${ }^{\text {"37 }} \mathrm{A}$ normative approach should also be more adaptable to addressing new, unforeseen problems. ${ }^{38}$

\section{MICROPRUDENTIAL REGULATION}

I next examine how microprudential regulation could improve the functioning of the components of the financial system-firms and markets-first by identifying their functions ${ }^{39}$ and thereafter by examining how regulation could be designed to correct market failures that impede those functions. ${ }^{40}$ This provides a less time-constrained perspective than the traditional approach of specifically tying regulation to the existing financial architecture. ${ }^{41}$ It also reveals that microprudential regulation cannot perfectly correct those market failures. Thereafter, in Part II of the Article, I attempt to conceptualize a more functional approach to macroprudential regulation that should be more effective than the existing ad hoc regulatory framework.

My analyses of functional approaches to microprudential and macroprudential regulation should not be confused with what is sometimes called a functional approach to financial supervision, in which the supervisory government agency's jurisdiction is based not on an entity itself (e.g., a bank) but on the business being transacted by an entity (e.g., government agency $\mathrm{X}$ would supervise a bank's lending activities and government agency $\mathrm{Y}$ would supervise the same bank's securitiesunderwriting activities). ${ }^{42} \mathrm{My}$ Article, in contrast, addresses

37. Cf. G.E. MoORE, PrInCIPIA ETHICA 59-63 (Thomas Baldwin ed., 2d ed. 1971) (distinguishing positive observations of what exist (in our case, such as tools in the toolkit) from normative analysis of what should be). This distinction between what exists and what should exist is especially meaningful when, as in our case, the former may result from lobbying.

38. Cf. Anabtawi \& Schwarcz, supra note 11 (observing that an institutional approach to financial regulation is "unlikely to be adaptive when the [financial] system is experiencing change"); Avgouleas, supra note 3, at 687-88 (observing that tying financial regulation to the existing financial infrastructure cannot capture new, unforeseen problems).

39. See infra Part I.A.

40. See infra Part I.B. Portions of Part I.B are based on Schwarcz, supra note 33 .

41. Cf. supra note 20 and accompanying text (observing that the traditional approach to microprudential regulation is tied to components of the financial system defined by the financial architecture).

42. See, e.g., Group OF THIRTy, THE Structure of Financial SuPERVISION: APPROACHES AND CHALlENGES IN A GLOBAL MARKETPlACE 13 (2008), http://www.davispolk.com/sites/default/files/files/Publication/5ee96bcc-efeb 
how financial regulatory rules should be substantively designed, not how bureaucratic supervision of rules should occur.

\section{A. IDENTIFYING FUNCTIONS}

Financial firms and markets have several key economic functions. The principal function is capital provision, allocation, and deployment (hereinafter, funding): the process of aggregating funds from multiple investors and then transferring the funds to firms that can productively use it. ${ }^{43}$ Traditional banks, for example, engage in funding by borrowing money from depositors and (other) investors and then lending the money to firms. Shadow banks engage in funding in a variety of ways, including using markets to raise money-such as by issuing securities of special-purpose entities (SPEs) to investors and using the proceeds to purchase, from firms, financial or other assets that will be the source of investor repayment. ${ }^{44}$ Markets can also be used more directly for funding, such as a firm issuing its own securities (e.g., commercial paper or bonds) to investors.

Economists also identify a range of other functions related to funding. These related functions involve risk management, behavior monitoring, and information processing. ${ }^{45}$ The riskmanagement function goes to diversifying investment risk in order to maximize the amount of investment. Different investors have different risk tolerances. Optimal diversification will attract both high-risk investors who want high rates of return to compensate for the risk, and lower-risk investors who are satisfied with lower rates of return. Risk management can oc-

-48a2-959a-d43cd85a10be/Preview/PublicationAttachment/c5c96139-d4cf -4909-9557-dec76b20721f/nazareth.group.thirty.jul12.pdf (explaining that under a functional approach, supervisory oversight is based on the business being transacted by the entity).

43. See Merton \& Bodie, supra note 3, at 5 (discussing the provision, allocation, and deployment of financial capital); see also id. at 12 (observing that "the primary function of any financial system is to facilitate the allocation and deployment of economic resources" across time and borders in an uncertain environment). Merton and Bodie observe that although "[o]ther functional classification schemes have been suggested in the finance literature," the choice of which "functional classification scheme to use depends on its effectiveness in analysis." Id. at 12 n.18, 26-28 (discussing several other such schemes).

44. This type of shadow banking is usually called securitization. See supra note 10 .

45. Cf. Lyu, supra note 12 (synthesizing economic views on the functions of the financial system). 
cur in many ways, including the issuance of securities with senior and subordinated payment priorities, third-party credit supports such as "monoline" insurance-company surety bonds, and other forms of "hedging," including credit-default swaps.

The behavior-monitoring function goes to reducing agency costs. Investors want to align the interests of firms and their managers, such as by incentivizing managers through the issuance of stock options. They sometimes also impose contractual covenants on firms responsible for repayment, to help ensure that those firms do not engage in excessively risky activities.

The information-processing function goes to reducing information asymmetry between investors and issuers of securities. ${ }^{46}$ Investors and issuers cannot efficiently agree on pricing (e.g., the interest rate on the securities) unless there is informational transparency. ${ }^{47}$ Whereas relationship-banking traditionally helped to ensure that bank lenders knew their customers, shadow banking (and even direct market-based financing) depends more on the disclosure of information to investors on a transaction-by-transaction basis. That is not efficient when investors individually do not have enough at stake to justify the necessary due diligence. For debt securities, credit ratings help to reduce information asymmetry through an economy of scale, but recent experience suggests that rating agencies-especially in the face of increasing complexity-may sometimes be unable to adequately understand and assess the risks. ${ }^{48}$

\section{B. Designing Functional MicRoprudential Regulation}

Next, consider how regulation should be designed to improve these functions. In general, markets are efficient absent market failures; hence the purpose of financial regulation should be to correct market failures. ${ }^{49}$ What are the market failures that impede these financial system functions?

46. Cf. Awrey et al., supra note 36 , at 1 (discussing the information costs that market participants must incur in order to value non-cash assets).

47. Cf. id. (observing that, other things being equal, higher information costs and uncertainty are associated with lower levels of market liquidity, higher volatility, and, lower asset prices).

48. Although, some allege that the rating-agency failures are also due to conflicts of interest. See, e.g., Martin Mayer, Credit Rating Agencies in the Crosshairs, BROOKINGS INSTITUTION (Aug. 2010), http://www.brookings.edu/ research/articles/2010/08/31-ratings-agencies-mayer.

49. See Paul A. SAMuelson \& William D. NoRdhaus, ECONOMics 756 (15th ed. 1995) (defining market failure as "[a]n imperfection in a price system that prevents an efficient allocation of resources"). My Article's discussion of 
To answer that, consider each function. In designing regulation to improve funding, we should focus on whether any market failures impede the ability of the financial system to aggregate funds from multiple investors or to transfer aggregated funds to firms that can productively use it. In designing regulation to improve risk management, we should focus on whether any market failures impede the ability of the financial system to provide risk-diversified products and investments. In designing regulation to improve behavior monitoring, we should focus on whether any market failures impede the ability of the financial system to align the interests of principals and their agents. And in designing regulation to improve information processing, we should focus on whether any market failures impede the reduction of information asymmetry.

\section{Regulation To Improve Funding}

What market failures impede the ability of the financial system to aggregate funds from multiple investors or to transfer aggregated funds to firms that can productively use them? These functions may be subject to information asymmetry and rationality failure ${ }^{50}$ each of which can undermine the reliability of pricing. ${ }^{51}$ Aggregating and transferring funds necessarily depends on reliable pricing. ${ }^{52}$

market failures focuses on financially motivating market participants, not on societal value choices such as whether markets should also have the goal of eliminating low incomes and poverty.

50. These functions may also be at least indirectly subject to-and thus might be improved by regulation that reduces-other market failures discussed below. For example, improving risk management, see infra notes 70-71 and accompanying text, might also help to improve the financial system's ability to aggregate and distribute funds.

51. $C f$. ROMAN FRYDMAN \& MiCHAEL D. GOLDBERG, BEyOND MECHANICAL MARKETS: ASSET PRICE SWINGS, RISK, AND THE ROLE OF THE STATE 94 (2011) (observing that "barring informational asymmetries and other market failures, markets populated by rational individuals are stable, in the sense that they set prices to fluctuate randomly around intrinsic value").

52. Cf. Katharina Pistor, On the Theoretical Foundations for Regulating Financial Markets, SELECTEDWORKS OF KATHARINA PISTOR 2 (June 2012) (unpublished paper), http://works.bepress.com/katharina_pistor/11 (observing that a current critique of the efficient market hypothesis, positing that markets accurately reflect prices, is that market actors are not "rational, autonomous actors [but are] instead beset by herd behavior"). Another factor that can undermine the reliability of pricing is the "Imperfect Knowledge Constraint": the fact that "information about the past or present does not equal knowledge about the future." Id. at 7 . Because microprudential regulation cannot correct this market failure, it is an example of a microprudential regulatory failure that could have systemic consequences-such as pricing mortgage-backed se- 
Regulation could therefore improve funding by reducing information asymmetry and rationality failure. Consider next how regulation could reduce rationality failure. ${ }^{53}$ Thereafter, in the context of examining how regulation could more generally improve information processing, consider how regulation could reduce information asymmetry.

Even in financial markets, humans have bounded rationality. In areas of complexity, for example, we tend to over rely on heuristics-broadly defined as simplifications of reality that allow us to make decisions in spite of our limited ability to process information. ${ }^{55}$ Modern finance has become so complex that the financial community routinely relies on heuristic-based customs, such as determining creditworthiness of securities by relying on formalistic credit ratings ${ }^{56}$ and assessing risk on financial products by relying on simplified mathematical models. ${ }^{57}$ Other simplifications are more psychologically based ${ }^{58} \mathrm{Re}-$ liance on a heuristic can become so routine and widespread within a community that it develops into a "custom"-in its common meaning of "a usage or practice common to many or to a particular place or class."

Without this reliance, financial markets could not operate. ${ }^{60}$ Nonetheless, this reliance can backfire when a heuristic-

curities off models that rely on past housing prices.

53. See infra notes 55-63 and accompanying text.

54. See infra notes $86-100$ and accompanying text.

55. Steven L. Schwarcz, Protecting Financial Markets: Lessons from the Subprime Mortgage Meltdown, 93 MiNN. L. REV. 373, 379-83, 404-05 (2008).

56. Christopher L. Culp, et al., Value at Risk: Uses and Abuses, 10 J. APPLIED CORP. FIN. 26, 27 (1998); Steven L. Schwarcz, Private Ordering of Public Markets: The Rating Agency Paradox, 2002 U. ILL. L. REV. 1, 1-3.

57. In operations research, for example, the term "heuristics" refers to "computationally simple models that allow people to ' . . . quickly [find] good feasible solutions." Konstantinos V. Katsikopoulos, Psychological Heuristics for Making Inferences: Definition, Performance, and the Emerging Theory and Practice, 8 DECISION ANALYSIS 10, 11 (2011) (quoting FREDERICK S. HILLIER \& GERALD J. LIEBERMAN, INTRODUCTION TO OPERATIONS RESEARCH 624 n.1 (7th ed. 2001)).

58. In psychology, the term "heuristic" refers to both informal and quantitative psychological processes that "in general . . . are quite useful, but sometimes . . . lead to severe and systematic errors.” Amos Tversky \& Daniel Kahneman, Judgment Under Uncertainty: Heuristics and Biases, 185 ScI. 1124, 1124 (1974). For a discussion of many common psychologically based simplifications and errors, see generally DANIEL KAHNEMAN, THINKING, FAST AND SLOW (2011).

59. Custom, MERRIAM-WEBSTER's COLLEGIATE DiCTIONARY 308 (11th ed. 2003).

60. See James P. Crutchfield, The Hidden Fragility of Complex Systems- 
based custom no longer reflects reality. In recent years especially, financial markets and products have innovated so rapidly that heuristic-based customs-and thus behavior based on those customs-have lagged behind the changing reality. The resulting mismatch, in turn, has led to massive financial failures, such as investors relying on credit ratings that no longer are accurate and members of the financial community assessing risk using simplified models that have become misleading. ${ }^{61}$

Overreliance on heuristics merely exemplifies rationality failure, which has a wide range. Thus, market participants follow the herd in their investment choices and are also prone to panic. ${ }^{62}$ Furthermore, due to availability bias, they are unrealistically optimistic when thinking about extreme events with which they have no recent experience, devaluing the likelihood and potential consequences of those events. ${ }^{63}$

Consequences of Change, Changing Consequences, in CULTURES OF CHANGE: SOCIAL ATOMS AND ELECTRONIC LIVES 98, 102-03 (Gennaro Ascione et al. eds., 2009) (noting the increasing structural complexity and fragility of modern markets, including financial markets, as part of "the world we built"); see also Manuel A. Utset, Complex Financial Institutions and Systemic Risk, 45 GA. L. REV. 779, 799-803 (2011) (discussing the complexity of financial markets and the bounded rationality of financial-community members, as well as the need for heuristics to process and analyze financial information); Markus K. Brunnermeier \& Martin Oehmke, Complexity in Financial Markets 5-8 (Sept. 10, 2009) (draft), http://scholar.princeton.edu/sites/default/files/ complexity_0.pdf (noting that because financial-community members have bounded rationality, they must simplify complex financial markets by using, for example, models and summaries); $c f$. Andrew G. Haldane, Exec. Dir., Fin. Stability, Bank of Eng., Address at the Federal Reserve Bank of Kansas City's 366th Economic Policy Symposium: The Dog and the Frisbee (Aug. 31, 2012) (observing that "heuristics may be the optimising response to a complex environment" and that "[f]ully defining future states of the world, and probabilityweighting them, is beyond anyone's cognitive limits").

61. See Steven L. Schwarcz \& Lucy Chang, The Custom-to-Failure Cycle, 62 DUKE L.J. 767, 770 (2012) (identifying a four-stage cycle-which Chang and I call the custom-to-failure cycle-that leads to failure: (i) reliance on heuristics that reasonably approximate reality; (ii) the development of customs based on those heuristics; (iii) changes that disconnect those customs from reality; and (iv) failures resulting from continued reliance on those customs).

62. For a thoughtful analysis of how rationality failures help to explain the financial crisis, see Geoffrey P. Miller \& Gerald Rosenfeld, Intellectual Hazard: How Conceptual Biases in Complex Organizations Contributed to the Crisis of 2008, 33 HARV. J.L. \& PUB. POL'Y 807 (2010). Also, herding behavior might not always be irrational per se; sometimes it generates social benefits. See Ramsey M. Raafat et al., Corrigendum: Herding in Humans, 13 TRENDS COGNITIVE SCI. 420 (2009).

63. See Iman Anabtawi \& Steven L. Schwarcz, Regulating Systemic Risk: Towards an Analytical Framework, 86 NOTRE DAME L. REV. 1349, 1366-67 
Because human nature cannot be easily changed, there appear to be limited regulatory solutions to the problem of rationality failure. The law could attempt to limit overreliance on heuristics, for example, by requiring financial firms to engage in more self-aware operational risk management and reporting. ${ }^{64}$ The law could also attempt to limit complexity, which exacerbates rationality failure, by limiting complex financial products. ${ }^{65}$ This could be done in several ways, including requiring an approval process for new complex financial products, possibly similar to that used by the U.S. Food and Drug Administration for approving new medications, ${ }^{66}$ or by requiring that financial products become more standardized, thereby making such products more understandable ${ }^{67}$ or by taxing complexity. ${ }^{68}$ Because the approaches to limit complexity would impose costs that could offset their benefits, they should not be undertaken without appropriate cost-benefit analysis. ${ }^{69}$

(2011) [hereinafter Anabtawi \& Schwarcz, Regulating Systemic Risk].

64. See Schwarcz \& Chang, supra note 61 , at 783-84 (providing examples of how this type of legal requirement could have made financial-community members more aware of the limitations of-and thus the potential for failure inherent in-value-at-risk ( $\mathrm{VaR}$ ) models, the application of old credit-rating methodologies to complex new financial products, and the making of undercollateralized loans expecting that the collateral will rise in value over time).

65. Id. at 785-86.

66. Compare Eric A. Posner \& E. Glen Weyl, An FDA for Financial Innovation: Applying the Insurable Interest Doctrine to 21st-Century Financial Markets, 107 NW. U. L. REV. 1307, 1307 (2013) ("We propose that when firms invent new financial products, they be forbidden to sell them until they receive approval from a government agency .... The agency would approve financial products [depending] on whether the product will likely be used more often for insurance than for gambling."), with Saule T. Omarova, License To Deal: Mandatory Approval of New Complex Financial Products, 90 WASH. U. L. REV. 63, 116 (2012) (proposing a similar regulatory scheme for complex financial products, but one that uses an "economic purpose" test requiring the financial institution "to make an affirmative showing that the proposed complex financial instrument has a bona fide economic purpose that promotes productive enterprise and does not merely provide another means of financial speculation or regulatory arbitrage.").

67. See Anabtawi \& Schwarcz, Regulating Systemic Risk, supra note 63, at 1390 (discussing, among other things, the Dodd-Frank Act's requirement that certain derivatives products be effectively standardized).

68. See Haldane, supra note 60 (suggesting that "there is a case for tackling complexity directly and at [its] source" by levying an "explicit regulatory charge").

69. Compare Cass R. Sunstein, The Real World of Cost-Benefit Analysis: Thirty-Six Questions (and Almost as Many Answers), 114 COLUM. L. REV. 167 (2014) (explaining how cost-benefit analysis works), with Robert B. Ahdieh, Reanalyzing Cost-Benefit Analysis: Toward a Framework of Function(s) and 


\section{Regulation To Improve Risk Management}

In designing regulation, consider whether any market failures impede the ability of the financial system to provide riskdiversified products and investments. Risk spreading can create benefits, such as investment diversification and more efficient allocation of risk. But if risk is spread too widely, it can become marginalized such that rational market participants individually lack the incentive to monitor it. ${ }^{70}$ Undermonitoring caused by this incentive failure appears to have contributed, at least in part, to the financial crisis. ${ }^{71}$

Regulation could therefore improve risk management by incentivizing monitoring. Designing those incentives, however, would be a regulatory challenge. One possible approach might be to require market participants to internalize the externalities of their risk-taking decisions, so they more fully bear the consequences of under-monitoring. ${ }^{72}$ This could be done, for example, by mandating that market participants-particularly those that are deemed systemically important-contribute to a systemic risk fund. ${ }^{73}$ Management-based (sometimes called process-based) regulation also has the potential to create monitoring incentives by requiring market participants to develop their own individualized, internal risk-management processes. ${ }^{74}$ For example, increasing the authority and independence of risk managers could attract more sophisticated risk managers, ${ }^{75}$ and linking management compensation to long-term firm goals rather than short-term firm profit can motivate managers to

Form(s), 88 N.Y.U. L. REV. 6 (2013) (discussing the complexities and varieties of cost-benefit analysis).

70. See Steven L. Schwarcz, Marginalizing Risk, 89 WASH. UNIV. L. REV. 487 (2012) [hereinafter Schwarcz, Marginalizing Risk].

71. Cf. Joe Nocera, Risk Mismanagement, N.Y. Times MAG. (Jan. 2, 2009), http://www.nytimes.com/2009/01/04/magazine/04risk-t.html; Jean-Claude Trichet, President of the European Cent. Bank, Speech Before the Fifth ECB Central Banking Conference (Nov. 13, 2008) (arguing that "the root cause of the [financial] crisis was the overall and massive undervaluation of risk across markets, financial institutions and countries").

72. See Schwarcz, Marginalizing Risk, supra note 70, at 509-10.

73. Id. at 510-11; cf. infra notes 255-62 and accompanying text (explaining how such a fund could be created and even privatized, and also discussing how the fund could reduce moral hazard and incentivize increased monitoring).

74. See Schwarcz, Marginalizing Risk, supra note 70, at 515.

75. Id. 
more closely monitor and communicate potential risks and limitations to their senior management. ${ }^{76}$

Other regulatory approaches might incentivize monitoring by reducing risk diversification. ${ }^{77}$ For example, regulation could restrict the issuance of securities unless, for each class of securities, at least one sophisticated investor holds a minimum unhedged position. ${ }^{78}$ Because any such regulation could impose significant costs, it should not be attempted without a clear understanding of its costs and benefits. ${ }^{79}$

\section{Regulation To Improve Behavior Monitoring}

In designing this regulation, consider whether any market failures impede the ability of the financial system to align the interests of principals and their agents. Scholars have long studied inefficiencies resulting from conflicts of interest between managers and owners of firms. There is, however, a much more insidious principal-agent failure: the intra-firm problem of secondary-management conflicts. ${ }^{80}$ The nub of the problem is that secondary managers are almost always paid under short-term compensation schemes, misaligning their interests with the long-term interests of the firm.

Complexity exacerbates this problem by increasing information asymmetry between technically sophisticated secondary managers and the senior managers to whom they report. For example, as the VaR, or value-at-risk, model for measuring investment-portfolio risk became more accepted, financial firms began compensating secondary managers not only for generating profits but also for generating profits with low risks, as measured by $\mathrm{VaR}^{81}$ Secondary managers turned to investment products with low VaR risk profiles, like credit-default swaps that generate small gains but only rarely have losses. They knew-but did not always explain to their superiors-that any losses that might eventually occur would be huge. ${ }^{82}$

76. Id. at 507 .

77. Id. at 516 .

78. Id.

79. Id. at 517 .

80. See Steven L. Schwarcz, Conflicts and Financial Collapse: The Problem of Secondary-Management Agency Costs, 26 YALE J. ON REG. 457 (2009) [hereinafter Schwarcz, Conflicts and Financial Collapse].

81. See, e.g., Philippe Jorion, VAlue at Risk: The New Benchmark For MANAGING FINANCIAL RISK 568 (3d ed. 2006).

82. See Schwarcz, Conflicts and Financial Collapse, supra note 80, at 460. 
In theory, firms can solve this principal-agent failure by paying managers, including secondary managers, under longerterm compensation schemes-e.g., compensation subject to clawbacks or deferred compensation based on long-term results. ${ }^{83}$ In practice, however, that solution would confront a collective action problem: firms that offer their secondary managers longer-term compensation might not be able to hire as competitively as firms that offer more immediate compensation. ${ }^{84}$

Regulation can solve the collective action problem, and thus correct the principal-agent failure, by requiring financial firms-or at least those that meet relevant criteria of materiality-to pay managers, including secondary managers, under longer-term compensation schemes. However, because good secondary managers can work in financial centers worldwide, international regulation may be needed to help fully solve the collective action problem. ${ }^{85}$

\section{Regulation To Improve Information Processing}

In designing regulation, consider whether any market failures impede the reduction of information asymmetry. ${ }^{86} \mathrm{Com}-$ plexity is the main cause of this "information failure." ${ }^{.77}$ Finan-

83. It appears that at least two financial firms, Goldman Sachs and Morgan Stanley, are beginning to implement this type of compensation policy. See Liz Moyer, On "Bleak" Street, Bosses in Cross Hairs, WALL ST. J. (Feb. 8, 2012), http://www.wsj.com/articles/SB10001424052970204136404577209383 447837986 (reporting that these firms "would seek to recover pay from any employee whose actions expose the firms to substantial financial or legal repercussions").

84. See, e.g., Kimberly D. Krawiec, The Return of the Rogue, 51 ARIZ. L. REV. 127, 157-58 (2009) (arguing that financial firms have had trouble balancing the discouragement of excessive risk-taking against the need to create profit-maximizing incentives and preferences).

85. The Basel capital accords exemplify global rules intended to help avoid prejudicing the competitiveness of firms-in this case, banks-in any given nation or region. See, e.g., Arie C. Eernisse, Banking on Cooperation: The Role of the G-20 in Improving the International Financial Architecture, 22 DUKE J. COMP. \& INT'L. L. 239, 254-56 (2012) (discussing the Basel III capital and liquidity framework and its emphasis on consistent global standards); Clyde Stoltenberg et al., The Past Decade of Regulatory Change in the U.S. and EU Capital Market Regimes: An Evolution from National Interests Toward International Harmonization with Emerging G-20 Leadership, 29 BERKELEY J. INT'L. L. 577, 615-44 (2011) (examining U.S. and E.U. efforts to adopt harmonized financial standards).

86. This regulation would also have the effect of improving funding by reducing information asymmetry. See supra notes 51-54 and accompanying text.

87. See generally Steven L. Schwarcz, Regulating Complexity in Financial 
cial markets and products are already incredibly complex, and that complexity is certain to increase. Profit opportunities are inherent in complexity, due in part to investor demand for securities that more precisely match their risk and reward preferences. Regulatory arbitrage increases complexity as market participants take advantage of inconsistent regulatory regimes both within and across national borders. ${ }^{88}$ And new technologies continue to add complexity not only to financial products but also to financial markets. ${ }^{89}$

Complexity is undermining disclosure, which, since the securities laws of the $1930 \mathrm{~s}$, has been the chief regulatory tool to reduce information asymmetry. ${ }^{90}$ The Dodd-Frank Act puts great stock in the idea of improving disclosure, ${ }^{91}$ but its efficacy will be limited. Some financial structures are getting so complex that they are effectively incomprehensible. ${ }^{92}$ Furthermore,

Markets, 87 WASH. U. L. REV. 211 (2009) [hereinafter Schwarcz, Regulating Complexity]. I have argued that there are two aspects to complexity: cognitive complexity, meaning that things are too complicated and non-linear to understand, and temporal complexity, meaning that systems work too quickly and interactively to control. Id. at 214-15. Engineers sometimes refer to temporal complexity as tight coupling. $I d$.

88. See generally Victor Fleischer, Regulatory Arbitrage, 88 TEX. L. REV. 227 (2011).

89. See Schwarcz, Regulating Complexity, supra note 87, at 214-15.

90. See, e.g., Cynthia A. Williams, The Securities and Exchange Commission and Corporate Social Transparency, 112 HARV. L. REV. 1197, 1209-35 (1999) (discussing the general purpose of disclosure in the Exchange Act and the Securities Act).

91. See, e.g., Dodd-Frank Wall Street Reform and Consumer Protection Act, Pub. L. No. 111-203 (2010), § 1103 (requiring additional disclosure); id. $\S 942$ (b) (requiring issuers of asset-backed securities to disclose information on the assets backing each tranche of security); $i d$. $\$ 945$ (requiring the SEC to issue rules requiring issuers of asset-backed securities to disclose the nature of the underlying assets); $i d$. $\S 951$ (requiring persons who make solicitations for the sale of all or substantially all of a corporation's assets to disclose their compensation arrangements to shareholders).

92. See, e.g., Lee C. Buchheit, Did We Make Things Too Complicated?, 27 INT'L. Fin. L. REv. 24, 24 (2008) (U.K.); David Barboza, Complex El Paso Partnerships Puzzle Analysts, N.Y. TIMES, July 23, 2002, at C1 ( "[O]ne industry giant, the El Paso Corporation, is growing ever more reliant on deals [using off-balance sheet partnerships] so complex that securities experts call them incomprehensible."). It appears hyperbolic to say that structures created by humans cannot be understood by humans. The larger problem may be that relatively few people can understand the structures and that many structures may not be able to be understood by any single person. Moreover, even if people could understand the structures, they may not be able to do so within the time frames that occur routinely in the market. In financial transactions, time is almost always a constraining factor. 
it may well be rational for an investor to invest in high-yield complex securities without fully understanding them. ${ }^{93}$

Moreover, even perfect disclosure would be insufficient to mitigate information failures that cause systemic risk. Individual market participants who fully understand the risk will be motivated to protect themselves but not necessarily the financial system as a whole. A market participant may well decide to engage in a risky but profitable transaction even though doing so could increase systemic risk because much of the harm from a possible systemic collapse would be externalized onto other market participants as well as onto ordinary citizens. ${ }^{94}$ I will later discuss this in the context of macroprudential regulation. ${ }^{95}$

Complexity also makes it difficult for regulators to understand, and thus effectively regulate, financial products and markets. There are at least three levels of complexity in financial markets: complexities of the assets underlying investment securities traded in financial markets and of the means of originating those assets; complexities of the investment securities themselves; and complexities of financial markets, which operate as systems. ${ }^{96}$ An understanding of these levels of complexity sometimes challenges experts at even the most sophisticated financial firms. ${ }^{97}$ Regulators that lack that expertise will be even more challenged to understand these levels of complexity.

93. Although most, if not all, of the risks on complex mortgage-backed securities were disclosed prior to the financial crisis, many institutional investors-including even the largest, most sophisticated, firms-bought these securities without fully understanding them. See Steven L. Schwarcz, Disclosure's Failure in the Subprime Mortgage Crisis, 2008 UTAH L. REV. 1109, 1110 [hereinafter Schwarcz, Disclosure's Failure]; cf. John D. Finnerty \& Kishlaya Pathak, A Review of Recent Derivatives Litigation, 16 FORDHAM J. CORP. \& FIN. L. 73, 74 (2011) (observing that court records reveal investors' misunderstandings about the nature of derivative financial instruments). There may be many reasons for this. For example, the investor simply may not have the staffing to evaluate the securities, whereas failure to invest would appear to-and in fact could-competitively prejudice the investor vis-à-vis others who invest. See Schwarcz, Disclosure's Failure, supra, at 1113-15.

94. See Schwarcz, Systemic Risk, supra note 24, at 206 (explaining this concept and describing it as a type of "tragedy of the commons"). It is a tragedy of the commons insofar as market participants suffer from the actions of other market participants; it is a more standard externality insofar as non-market participants suffer from the actions of market participants.

95. See infra note 178 and accompanying text.

96. See Schwarcz, Regulating Complexity, supra note 87, at 216-36.

97. Cf. Schwarcz, Disclosure's Failure, supra note 93, at 1113 (arguing that although the disclosure documents describing complex asset-backed securities generally complied with federal securities law, investors did not fully 
Moreover, the extraordinary income gap between financial industry employees and their regulatory counterparts makes it likely that the expertise of regulators will be far less than that of their industry counterparts. In the United States, for example, financial industry employees earn at least twice as much as their regulatory counterparts. ${ }^{98}$ This gap enables the financial industry to bid away at least some of the smarter employees, thereby putting administrative agencies at a disadvantage. ${ }^{99}$ Reducing the income gap would be a politically challenging, if not impossible, task; even if government could increase the incomes of financial regulators to private-sector levels, the financial industry would be motivated to match and exceed any such increases that drew away significant talent. ${ }^{100}$ This creates a new type of information asymmetry. Scholars traditionally have studied information asymmetries between regulators and the regulated by focusing almost exclusively on information acquisition and product-development lag time. ${ }^{101}$ That focus is limited to regulators obtaining information. In contrast, the income gap creates an information asymmetry based more on potential differences in intellect and abilities between regulators and the regulated. That focus goes not to obtaining information; instead, it goes to the ability of financial regulators to process the information, once obtained.

Regulation might be somewhat effective in correcting these market failures. As already discussed, regulation could attempt

understand those securities or their risks); Schwarcz, Regulating Complexity, supra note 87, at 243 (observing that even the most sophisticated investors lost money in the financial crisis).

98. See Steven L. Schwarcz, Intrinsic Imbalance: The Impact of Income Disparity on Financial Regulation, 78 L. \& CONTEMP. PROBS. 97, 100 (2015) [hereinafter Schwarcz, Intrinsic Imbalance] (writing for the symposium Issue on "The Administrative Law of Financial Regulation").

99. Id. (finding that the income gap between industry and regulators is much larger for financial regulation than for non-financial regulation); $c f$. Bos. CONSUlting GRP., U.S. SEC. \& EXCH. COMM'N, ORGANIZATIONAL STUDY AND REFORM 53-54 (Mar. 10, 2011), 2011 WL 830339 (observing that the SEC's senior management considers the SEC's staff analytical capabilities to be only average or even below, and attributing that to the SEC's relatively flat budget and its resulting hiring difficulties); Howell E. Jackson, Variation in the Intensity of Financial Regulation: Preliminary Evidence and Potential Implications, 24 YALE J. ON REG. 253, 273 (2007) (suggesting that the regulatory budget per staff member may indicate staff quality).

100. See Schwarcz, Intrinsic Imbalance, supra note 98, at 117. This Article finds that other potential responses to attempt to correct regulatory failures resulting from the income gap are even more "second best."

101. Id. at 106 . 
to reduce complexity by regulating financial products, such as by requiring approval of new financial products or requiring that products become more standardized. ${ }^{102}$ Regulation could also require supplemental protections-such as guarantees and certifications of quality ${ }^{103}$ - to address the insufficiency of disclosure. ${ }^{104}$ Although they would not help reduce information asymmetry per se, supplemental protections would help to counteract the harmful effects of a lack of informational transparency by shifting some of the risk from the securities investor back to the securities issuer. ${ }^{105}$ Regulation might also help to improve information processing by, for example, increasing non-monetary attraction to public-sector regulatory jobs. ${ }^{106}$ There are, however, no complete solutions to the problem of financial information failure. Indeed, I believe that complexity will be the greatest future challenge to designing effective financial regulation.

The analysis so far has conceptualized microprudential regulation by identifying the key economic functions of the financial system and examining how regulation could be designed to correct market failures that impede those functions. Among other things, this analysis revealed that microprudential regulation cannot perfectly correct those market failures. I next add to the regulatory framework by examining ways in which macroprudential regulation could more directly protect the financial system, as a system. In that context, I will show that some of the inevitable market failures can have systemic consequences. For this and other reasons, macroprudential regulation should not merely operate ex ante, attempting to eliminate vulnerabilities of the financial system that could trigger shocks that have a systemic impact on the system's functions (hereinafter, systemic shocks); it should also

102. See supra notes $65-67$ and accompanying text. Again, because limiting complexity may impose costs that offset the benefits, this should not be undertaken without appropriate cost-benefit analysis.

103. See Schwarcz, Disclosure's Failure, supra note 93, at 1119-21.

104. See id. at 1118. These protections would be in addition to, not in place of, disclosure since even insufficient disclosure can provide value by reducing information asymmetry, and disclosure has other justifications beyond the asymmetric information problem. $I d$.

105. See id. at 1119 (noting that supplemental protections can help "shift the risk from the buyer to the seller").

106. See Schwarcz, Intrinsic Imbalance, supra note 98, at 111-13. 
operate ex post, breaking the transmission of systemic shocks and mitigating their impact. ${ }^{107}$

\section{MACROPRUDENTIAL REGULATION}

Policymakers and regulators rhetorically recognize the need for macroprudential regulation. ${ }^{108}$ In reality, though, they tend to take an ad hoc approach, approaching macroprudential regulation as merely a loose assortment of "tools" in their "toolkit." ${ }^{109}$ This ad hoc approach has several possible explanations: macroprudential regulatory "policies remain somewhat poorly defined," [macroprudential regulatory] tools should be used to promote financial stability" as opposed to promoting microprudential goals such as "safety and soundness or consumer protection."111 This ambiguity is compounded by fragmented supervisory authority, in which the power to use macroprudential tools is sometimes given to regulators who lack an explicit mandate to promote financial stability. ${ }^{112}$

Whatever the explanation, an ad hoc approach to macroprudential regulation results in either overly specific regulatory proposals without realistic guidance as to their application or use, or overly broad propositions that provide little

107. See Anabtawi \& Schwarcz, supra note 11; cf. Eichengreen, supra note 28 , at 21 (" $[\mathrm{N}]$ ot all risks that materialize can be anticipated, and not all risks that are anticipated can be avoided.").

108. See, e.g., Frank Ahrens, Obama: We're Moving Toward Broader Regulation, WASH. POST (Mar. 18, 2009, 12:38 PM), http://voices.washingtonpost .com/economy-watch/2009/03/obama_were_moving_toward_broad.html; Daniel K. Tarullo, U.S. Fed. Reserve Governor, Address at the Yale Law School Conference on Challenges in Global Financial Services: Macroprudential Regulation (Sept. 20, 2013); Janet Yellen, U.S. Fed. Reserve Chair, Address at the 2014 Michel Camdessus Central Banking Lecture, International Monetary Fund: Monetary Policy and Financial Stability (July 2, 2014).

109. See supra notes 35-36 and accompanying text.

110. Elliott et al., supra note 19, at 2. U.S. regulators recognize there much needs to be done in order to design macroprudential regulatory policies. See, e.g., Bernanke, supra note 19 (suggesting macroprudential policies to address "critical gaps and weaknesses in the U.S. financial system"). For a discussion of ad hoc macroprudential regulation outside the United States, see Kern Alexander \& Steven L. Schwarcz, The Macroprudential Quandary: Unsystematic Efforts to Reform Financial Regulation, in RECONCEPTUALISING GLOBAL FINANCE AND ITS REgUlation (Ross Buckley et al. eds.) (forthcoming Mar. 2016).

111. Elliott et al., supra note 19 , at 2.

112. See id. at 7 . 
concrete regulatory guidance. As an example of the former, ${ }^{113}$ the "emergent macroprudential 'toolkit' as currently constituted" is said to comprise cross-sectoral leverage ceilings, credit and credit-growth ceilings, reserve and capital buffer requirements, liquidity minima and maturity mismatch maxima, dynamic countercyclical provisioning, and surveillance and data collection. ${ }^{114}$ Although this litany represents a range of diverse approaches, it provides no guidance as to which "tools" should be used in which circumstances, or as to how the tools should be calibrated. ${ }^{115}$ The misapplication of these tools may be as likely to cause financial problems, however, as to solve them. ${ }^{116}$ More significantly, even if the tools turn out to be correctly calibrated and applied today, they almost certainly-if not recalibrated-will lose their utility over time.

113. That is, overly-specific regulatory proposals.

114. Hockett, supra note 25 , at $12-13$.

115. Indeed, even in the relatively narrow context of banking, senior officials propose diverse "policy instruments" without clarity or definition as to how or when to deploy them. $C f$. EUROPEAN SYSTEMIC RISK BD., FlaGSHIP REPORT ON MACRO-PRUDENTIAL POLICY IN THE BANKING SECTOR 8-9 (2014), http://www.esrb.europa.eu/pub/pdf/other/140303_flagship_report.pdf?d0f12e52 6e9b00e7c4a137f97776b96c (suggesting that European Union Member States use various macroprudential tools, but offering little guidance as to how and when to use them). To some extent, the ambiguity of regulatory guidelines may be politically intentional. See, e.g., E-mail from Charles Klingman, Office of the Indep. Member, U.S. Fin. Stability Oversight Council, to the author (May 12, 2014) (on file with author) ("If a regulator is too specific or clear in how to use tools, then there will be those stating that such usage would be deeply unfair and improper. So, the tools are rarely well targeted because such targeting would be the subject of deep controversy, and if the likely targeting of a tool is readily discernable from the tool itself then it is also subject to withering attack."). Mr. Klingman cautions that the views expressed in this email are solely his own, and not those of his employer, any coworkers, or the government. $C f$. Awrey et al., supra note 36 , at 5 (observing that statutory incompleteness is sometimes part of the regulatory design, such as the absence of detailed legislative frameworks governing the activities of central banks in many jurisdictions, enabling them to pursue a policy of "constructive ambiguity" or other discretion to undertake extraordinary measures in the interests of maintaining financial stability).

116. Cf. Awrey et al., supra note 36, at 2 (observing that although legal "rules are necessary to support the development of financial markets, they are also a potentially significant source of financial instability"); Charles A.E. Goodhart, The Macro-Prudential Authority: Powers, Scope and Accountability, OECD J. FIN. MKT. TRENDS (Sept. 2011), http://www.oecd.org/finance/ financial-markets/48979021.pdf (last accessed Mar. 11, 2016) (arguing that macroprudential authorities should do more analysis to understand how the various tools will work). 
For example, because economic growth is strongly tied to the availability of credit, ${ }^{117}$ overly restrictive credit or creditgrowth ceilings could cause the economy to contract. ${ }^{118}$ Yet the very justification for these ceilings-the "compelling evidence that credit booms tend to precede particularly severe and prolonged downturns"119 -is questionable. Evidence of the mere tendency for credit booms to precede severe economic downturns does not prove a causal relationship.

Furthermore, even if that causal relationship could be proved, the evidence does not yet appear to provide a clear basis for quantifying a limitation on credit growth. And even if such a limitation could be quantified for today's economy, it would almost certainly need to be recalibrated from time to time in light of the future economic conditions lest it become overly restrictive, and thus harmful to the economy. ${ }^{120}$ Being subject, however, to the same types of costs and political interference previously discussed, ${ }^{121}$ future recalibrations would be dubious.

The misapplication of capital requirements ${ }^{122}$ could also backfire. ${ }^{123}$ The regulatory reform dialogue increasingly is focusing on a countercyclical and flexible approach to capital requirements. ${ }^{124}$ Finance, and especially banking, is by nature

117. See, e.g., GeOrge CoOper, The Origin of Financial Crises: CenTRAL BANKS, CREDit BubBles, AND THE EFFiCIENT MARKET FALlaCy 121 (2008).

118. Id. (observing that when credit contracts, so will the economy).

119. Elliott et al., supra note 19, at 2 (observing this justification for the "growing support for the view that policymakers should use a variety of tools to minimize ... excessive credit growth" that could fuel asset-price bubbles). They also observe that some economists even conclude from this evidence that the "primary purpose" of macroprudential tools is "controlling credit growth." Id.

120. See supra notes $117-18$ and accompanying text.

121. See supra notes 7-8 and accompanying text.

122. Capital requirements are intended to protect financial institutions against unexpected losses. Alexander \& Schwarcz, supra note 110, at 11. Capital requirements in their modern form-based on ratios rather than fixed dollar amounts-were introduced into banking regulation in the 1980s. Elliott et al., supra note 19, at 34 (discussing how bank regulators switched from using capital requirements based on fixed dollar amounts to capital requirements based on the ratio of capital to total assets, and how the Basel I Accord spread that latter regulatory approach internationally).

123. The misapplication of leverage could additionally backfire. See infra note 233 and accompanying text.

124. See Kristin N. Johnson, Macroprudential Regulation: A Sustainable Approach to Regulating Financial Markets, 2013 U. ILL. L. REV. 881, 916 (discussing flexible capital requirements as a macroprudential tool); Richard 
procyclical: the increased availability of capital stimulates economic growth. ${ }^{125}$ Historically, financial regulation has tended to be procyclical as well-loosening during booms and becoming stricter after crises. ${ }^{126}$ The rationale for countercyclical capital requirements is that they would help to moderate economic growth, discouraging the buildup of imbalances during economic booms and bubbles (by reducing excessive risk-taking and credit expansion). ${ }^{127}$

But countercyclical capital requirements are only as good as the accuracy of the indicators that determine their timing and application. Potential indicators include GDP growth, credit conditions, asset prices, banking performance and soundness indicators, leverage ratios, and credit and liquidity spreads. ${ }^{128}$ There has been debate, however, about whether countercyclical regulation is actually feasible given that it is virtually impossible to know ex ante whether a financial cycle is rational or merely a bubble. ${ }^{129}$ Furthermore, countercyclical regulation's effectiveness could be undermined by regulatory arbitrage if the measures are not analogously applied to relevant shadowbanking activities. ${ }^{130}$

Accuracy is critical because the mistiming or misapplication of countercyclical regulation can have unintended adverse

Berner, Dir. of Office of Fin. Research, Remarks at the Joint Conference of the Federal Reserve Bank of Cleveland and Office of Financial Research, Financial Stability Analysis: Using the Tools, Finding the Data (May 30, 2013) (identifying countercyclical capital requirements as a tool to reduce or neutralize "threats to financial stability").

125. See Haocong Ren, Countercyclical Financial Regulation 3 (World Bank, Working Paper No. 5823, 2011), http://elibrary.worldbank.org/doi/ pdf/10.1596/1813-9450-5823 (observing that during economic booms and bubbles, credit expansion outpaces economic growth, and that during economic downturns, lending contracts, further worsening economic prospects).

126. See Brett H. McDonnell, Designing Countercyclical Capital Buffers, 18 N.C. BANKING INST. 123, 123 (2013) (noting that the same factors that cause cycles in the financial markets, cause financial regulations to reinforce the cycles); see also id. at 124-30 (discussing how capital requirements are procyclical when they force banks to cut back on lending due to faltering capital positions because of decreasing credit quality and increasing losses, further deteriorating economic performance and resulting in even more credit losses).

127. See Ren, supra note 125 , at $4-5$.

128. Id. at 6 .

129. See Patricia A. McCoy, Countercyclical Regulation and Its Challenges (Bos. Coll. Law Sch., Legal Studies Research Paper No. 351, 2015), http:// papers.ssrn.com/sol3/papers.cfm?abstract_id=2568261 (arguing that even for real estate bubbles, no one has adequate information ex ante to know for sure whether the price increases are rationale or merely a bubble).

130. See Ren, supra note 125 , at 8. 
consequences, as illustrated by the notorious savings and loan (S\&L) crisis of the 1980s in the United States. S\&L institutions faced a period in which rising interest rates made lending less attractive to borrowers. ${ }^{131}$ To avoid having to commit government funds to bail out financially stressed institutions, regulators relieved the stress by engaging in a type of countercyclicality: they eased the capital ratios in order to "help banks muddle through [that] difficult period." 132 However, the result of that forbearance, in conjunction with other regulatoryrelief steps, was to rapidly expand the size of the S\&L industry-from $\$ 686$ billion in 1982 to $\$ 1.1$ trillion in $1985 .^{133}$ When the S\&L industry eventually collapsed, its increased size led to the largest federal bailout in history up to that time. ${ }^{134}$

This example illustrates the potentially harmful consequences of ad hoc macroprudential regulation that relies on overly specific regulatory proposals without realistic guidance as to their application or use. It also illustrates the harm resulting from the (likely) failure to recalibrate the proposals in the future. Other ad hoc approaches to macroprudential regulation have yielded overly broad propositions that provide little concrete regulatory guidance. ${ }^{135}$

For example, Professor Katharina Pistor and others have observed "four interwoven propositions" that underlie the relationship of finance and law. First, financial markets are made up of private contracts and public rules. Second, public rules, and associated legal institutions, support these contracts and their enforcement. Third, the financial system is inherently hierarchical in that the only true lenders of last resort are the sovereign states that control their own currency and are able to issue debt in that currency, and that rights and obligations under contracts, private rules, and public laws to which market participants are subject may not be strictly enforced if non-

131. Elliott et al., supra note 19, at 34 .

132. Id. (observing that this countercyclicality was imprecisely implemented).

133. Id. at 35. The eased capital ratios enabled rapid growth. For example, a $\$ 2$ million dollar investment in a new S\&L could be leveraged into $\$ 1.3$ billion in assets. See 1 Div. OF REsearch \& Statistics, FED. Deposit Ins. CORP., HISTORY OF THE EIGHTY'S-LESSONS FOR THE FUTURE 172-73 (1997), https://www.fdic.gov/bank/historical/history/167_188.pdf.

134. See Lawrence A. Cunningham \& David Zaring, The Three or Four Approaches to Financial Regulation: A Cautionary Analysis Against Exuberance in Crisis Response, 78 GEO. WASH. L. REV. 39, 51 (2009).

135. See supra notes 113-14 and accompanying text. 
enforcement is needed to protect the financial system during a crisis. Fourth, while these rules and laws are necessary to support the development of financial markets, they are also a potentially significant source of financial instability. ${ }^{136}$ These observations ring true, but are too general to inform the making of actual financial regulation.

An ad hoc approach to macroprudential regulation can also raise other concerns. Without a conceptual framework, the rulemaking process may be costlier ${ }^{137}$ and, more significantly, the resulting rules run the risk of being "at best redundant and at worst" contradictory. ${ }^{138}$ That, in turn, increases opportunities for regulatory arbitrage ${ }^{139}$ which has been cited as contributing to the financial crisis. ${ }^{140}$ Ad hoc regulation may also give regulators and policymakers a false sense of security. ${ }^{141}$ Finally, ad hoc regulation can skew the regulatory focus. For example, by focusing on the "risks arising from leverage on the balance sheet of banks," unleveraged financial institutions, such as asset managers, contribute to risk in the financial system. ${ }^{143}$

136. Awrey et al., supra note 36 , at $2-5$ (referring to this as the legal theory of finance).

137. See, e.g., Steven L. Schwarcz, A Fundamental Inquiry into the Statutory Rulemaking Process of Private Legislatures, 29 GA. L. REV. 909, 917-18 (1995). The proposed rules may be unrelated to the problem that spurred the rulemaking. $I d$. at 918 . Or, crafting the proposals may require more policymakers than would otherwise be needed. Id. at 917-18. Further, any sunk costs of the rulemaking process can induce policymakers to enact unnecessary or even undesirable rules, to try to justify those costs. Id. at 918-19.

138. David Mellinkoff, The Language of the Uniform Commercial Code, 77 YALE L.J. 185, 185, 225 (1967).

139. Cf. Merton \& Bodie, supra note 3, at 10 (suggesting that regulation tied to the existing financial architecture encourages "financial innovation [that] sometimes appears to threaten the stability of the system, by providing the means to circumvent institutionally based regulations at low cost").

140. See Tobias Berg et al., A Certification Model for Regulatory Arbitrage: Will Regulatory Arbitrage Persist under Basel III?, 21 J. FIXED INCOME 39, 39 (2011); Charles Whitehead, The Goldilocks Approach: Financial Risk and Staged Regulation, 97 CORNELL L. REV. 1267, 1275-76 (2012) (arguing that banks exploited loopholes in the regulatory framework, allowing them to keep lower capital buffers during the pre-crisis upswing, leaving them with too little capital during the crisis).

141. See, e.g., Samuel G. Hanson et al., A Macroprudential Approach to Financial Regulation, 25 J. ECON. PERSPS. 3, 25 (2011) (observing that the "individual regulated banks may be safer than they were before" but the "overall system of credit creation may not").

142. Andrew G. Haldane, Exec. Dir., Fin. Stability, Bank of Eng., Speech at the London Business School: The Age of Asset Management? 13 (Apr. 4, 2014).

143. See id. 
To help mitigate these concerns, I next attempt to conceptualize a more functional, and less ad hoc, approach to macroprudential regulation. ${ }^{144}$

\section{A. IDENTIFYING FUNCTIONS}

The financial system is a "system": a group of interrelated elements whose functioning as a whole is distinct from the functioning of its component parts. ${ }^{145}$ The function of the financial system as a whole is to serve as a network ${ }^{146}$ within which its component elements, firms and markets, can achieve the economic functions previously identified and discussed. ${ }^{147}$

Law is integral to achieving economic functions, and, indeed, the financial system can be characterized as a law-related system. ${ }^{148}$ This characterization is supported by legal theories of finance, which observe that law is endogenous to finance ${ }^{149}$ and that financial markets are made up of private contracts between market participants that create financial claims (e.g., equity, debt, derivatives) as well as public laws and legal institutions that support these contracts and their enforcement. ${ }^{150}$

Regulation of a law-related system, as a system, should have two purposes: "to prevent harmful conduct" that can impair the system's ability to serve as a network within which its component elements can perform their functions, and to "avoid harmful consequences" of conduct that cannot be prevented. ${ }^{151}$

144. I do not, however, attempt to propose the final form of any macroprudential rules because there is "as yet no clear consensus on what constitutes the optimal degree of financial stability or systemic risk for which macroprudential regulators should strive." Hockett, supra note 25, at 11.

145. See Anabtawi \& Schwarcz, supra note 11, at 78 (also citing Arthur D. Hall \& Robert E. Fagan, Definition of System, 1 GEN. SYS. 18, 18 (1956)); see also Donella H. Meadows, Thinking IN Systems: A PRIMER 22 (Diana Wright ed., 2008).

146. Until the financial crisis, the network functions of the financial system-in which the component elements, firms and markets, are highly interrelated-were underappreciated. Anabtawi \& Schwarcz, supra note 11, at 88.

147. See supra notes $43-48$ and accompanying text.

148. Anabtawi \& Schwarcz, supra note 11, at 87 (explaining why the pervasiveness of financial regulation establishes law as an "integral element of the financial system").

149. Cf. Rafael La Porta et al., Law and Finance, 106 J. PoL. ECON. 1113 (1998) (explicitly linking the importance of law to finance).

150. See, e.g., Katharina Pistor, A Legal Theory of Finance, 41 J. CoMP. ECON. 315, 315 (2013); Awrey et al., supra note 36.

151. Anabtawi \& Schwarcz, supra note 11, at 92 (citing Robert Charles Clark, The Soundness of Financial Intermediaries, 86 YALE L.J. 1, 10-11, 2426 (1976)); cf. Lynn M. LoPucki, The Systems Approach to Law, 82 CoRNELL L. 
Next, consider how that informs the design of functional macroprudential regulation.

\section{B. Designing Functional Macroprudential Regulation}

Functional regulation of the financial system, as a lawrelated system, should therefore at least focus on preventing harmful conduct that can impair the financial system's ability to serve as a network within which firms and markets can perform their economic functions, and avoiding harmful consequences of any such conduct that cannot be prevented. In reality, though, that focus should be broadened beyond "conduct" because, as will be shown, ${ }^{152}$ non-conduct-related vulnerabilities of the financial system can also impair those functions. Furthermore, in describing that focus, recall that vulnerabilities of the financial system that can impair its functions are defined as potential triggers of systemic shocks. ${ }^{153}$

As so restated, functional macroprudential regulation should focus on limiting the triggers of systemic shocks and mitigating the harm from systemic shocks that nonetheless occur by breaking the transmission and limiting the impact of those shocks. ${ }^{154}$ I next examine how to design that regulation.

\section{Regulation To Limit the Triggers of Systemic Shocks}

Ideal macroprudential regulation would act ex ante, limiting the triggers of systemic shocks. ${ }^{155}$ Several structural vulnerabilities of the financial system can trigger systemic shocks. Shadow banking can increase those vulnerabilities.

REV. 479, 502-03 (1997) (detailing the positive method of attributing goals to law-related systems).

152. See infra notes 156-66 and accompanying text (discussing maturity transformation as a vulnerability of the financial system that can trigger systemic shocks); see also infra notes 187-95 and accompanying text (discussing other non-conduct-related vulnerabilities of the financial system that can trigger systemic shocks).

153. See supra note 107 and accompanying text.

154. Cf. Anabtawi \& Schwarcz, supra note 11, at 93 (articulating similar goals); see also id. at 102 ("Systems analysis offers two types of defensive strategies against the spread of financial failures. The first approach is to prevent the failures from occurring in the first place. The second is to act on the system's elements and interconnections in order to mitigate the systemic consequences of a failure should it nonetheless occur." (footnote omitted)).

155. Cf. Steven L. Schwarcz, Keynote Address, Ex Ante Versus Ex Post Approaches to Financial Regulation, 15 CHAP. L. REV. 257, 258 (2011) ("Once a failure occurs, there may already be economic damage, and it may be difficult to stop the failure from spreading and becoming systemic."). 
Maturity Transformation. The classic structural vulnerability is maturity transformation: the asset-liability mismatch that results from the short-term funding of long-term projects. ${ }^{156}$ This mismatch creates a "liquidity default risk" that borrowers will be unable to repay their lenders. According to some scholars, illiquidity is the fundamental source of financial failure. ${ }^{157}$

A bank "run" is the typical (though far from the only) example of maturity transformation leading to a liquidity default. In a bank run, panicked depositors will collectively demand their money. If, as is usual, the long-term maturities of the bank's assets cannot generate cash quickly enough to pay the current depositor demands, the bank will default. ${ }^{158}$ And if (again, as is usual) the defaulting bank is interconnected with other banks, the defaulting bank's failure to pay its obligations to those other banks can, in turn, deprive those other banks of money to pay their creditors-with the chain spreading. ${ }^{159}$

Shadow banking also uses maturity transformation, ${ }^{160}$ and, indeed, shadow-bank maturity transformation was at the core of the financial crisis. ${ }^{161}$ For example, ABCP conduits and

156. Economists sometimes refer to the short-term funding of long-term projects as a form of maturity transformation or as an asset-liability mismatch. See, e.g., Huberto M. Ennis \& Todd Keister, Bank Runs and Institutions: The Perils of Intervention, 99 AM. ECON. REV. 1588, 1590 (2009) ("Money market funds and other arrangements perform maturity transformation by investing in long-term assets while offering investors the ability to withdraw funds on demand.").

157. See Awrey et al., supra note 36 , at 1 ("In the absence of liquidity constraints, . . . market participants could rest easy in the knowledge thatwhatever unforeseen contingencies might arise ex post-it will be possible for them to obtain refinancing.").

158. See, e.g., R.W. HAFER, THE FEDERAL RESERVE SyStem: AN ENCYClOPEDIA 145 (2005) (observing that a bank's cash reserves are often less than five percent of its deposits); Jonathan R. Macey \& Geoffrey P. Miller, Bank Failures, Risk Monitoring, and the Market for Bank Control, 88 CoLUM. L. REV. 1153, 1156-57 (1988) (linking bank runs and depositor collective action problems).

159. See Chris Mundy, The Nature of Risk: The Nature of Systemic RiskTrying To Achieve a Definition, 12 BALANCE SHEET 29, 29 (2004) (referring to bank runs as the "classic systemic risk").

160. See, e.g., Avgouleas, supra note 3, at 666 (observing that maturity transformation is the "main activity" of shadow banks).

161. See, e.g., Gary Gorton \& Andrew Metrick, Regulating the Shadow Banking System, in BROOKINGS PAPERS ON ECONOMIC ACTIVITY 261 (2010), http://www.brookings.edu/ /media/projects/bpea/fall-2010/2010b_bpea_

gorton.pdf (discussing sale and repurchase (repo) agreements in the context of the financial crisis of 2007-2009); Daniel Covitz et al., The Evolution of a Financial Crisis: Panic in the Asset-Backed Commercial Paper Market 1 (Fed. 
$\mathrm{SIVS}^{162}$ routinely issued short-term commercial paper to invest in financial assets having long-term maturities. ${ }^{163}$ Federal Reserve Board economists have observed that the inability of many ABCP conduits to roll over their short-term commercial paper in the last five months of 2007 "played a central role in transforming concerns about the credit quality of mortgagerelated assets into a global financial crisis." ${ }^{164}$ Similarly, moneymarket mutual funds ${ }^{165}$ also provided short-term loans, essentially withdrawable on demand, to fund long-term projects. ${ }^{166} \mathrm{In}$ mid-September 2008, when one such fund "broke the buck"167 the first time in fourteen years that happened to a money-

Reserve Bd. Fin. \& Discussion Series, Working Paper 2009-36, 2009), http:// www.federalreserve.gov/pubs/feds/2009/200936/200936pap.pdf (arguing that maturity transformation "played a central role in transforming concerns about the credit quality of mortgage-related assets into a global financial crisis"); see also Viral V. Acharya \& S. Viswanathan, Leverage, Moral Hazard, and Liquidity, 66 J. FIN. 99, 103 (2011) (observing that short-term funding of long-term projects "played an important role in the financial crisis of 2007 to 2009 and the period preceding it"); Kyle Glazier, Bernanke: Financial Crisis Was a Structural Failure, BOND BUYER (Apr. 13, 2012), http://www.bondbuyer .com/news/bernanke-speech-financial-crisis-structural-failure-1038520-1.html (last visited Mar. 11, 2016) (quoting Federal Reserve Board Chairman Ben Bernanke as saying that "a key vulnerability of the [disintermediated financial] system was the heavy reliance ... on various forms of short-term wholesale funding"); Martin H. Wolfson, Minsky's Theory of Financial Crisis in a Global Context, 36 J. ECON. IssuEs 393, 394 (2002) (describing Minsky's theory that market fragility grows as debt levels rise and that the proportion of debt will increase as firms use short-term debt to fund long-term financial assets).

162. See supra note 10 (referencing these shadow-bank entities).

163. See Markus K. Brunnermeier, Deciphering the Liquidity and Credit Crunch 2007-2008, 23 J. ECON. PERSPS. 77, 79 (2009); see also SCOTT BESLEY \& EUGENE F. BRIGHAM, PRINCIPLES OF FINANCE 29 (4th ed. 2008) (discussing maturity transformation in the context of repo lending). The business model of ABCP conduits and SIVs is very similar to that of banks in that they borrow short-term and lend long-term. See, e.g., Structured Investment Vehicle (SIV), MONEYTERMS, http://moneyterms.co.uk/siv (last visited Mar. 11, 2016) (discussing the business model of SIVs).

164. Covitz et al., supra note 161. The European Central Bank also has identified short-term funding of long-term projects as "a major amplification mechanism in situations of stress," which can particularly "foster systemic risks ... if [it] takes place outside the regulated [financial] system." Klara Bakk-Simon et al., Shadow Banking in the Euro Area: An Overview, in European CENT. BANK, OCCASIONAL PAPER SERIES 24 (European. Cent. Bank. No. 133, Apr. 2012).

165. See supra note 10.

166. See Bryan J. Noeth et al., Is Shadow Banking Really Banking?, 19 REGIONAL ECONOMIST 8, 9 (2011).

167. This means that the fund's price per share, or net asset value (NAV), fell below $\$ 1.00$ - the point at which fund investors will begin losing money. 
market mutual fund ${ }^{168}$-fund investors industry-wide raced to try to withdraw their investments from any remaining shortterm assets before other investors depleted those assets-the effective equivalent of a bank run. ${ }^{169}$

Although maturity transformation is a vulnerability of the financial system, it is also a benefit. Using short-term debt to fund long-term projects is attractive because, if managed to avoid a default, it tends to lower the cost of borrowing. ${ }^{170}$ The interest rate on short-term debt is usually lower than that on long-term debt because, other things being equal, it is easier to assess a borrower's ability to repay in the short term than in the long term and long-term debt carries greater interest-rate risk. ${ }^{171}$

Regulation should not, therefore, attempt to prohibit maturity transformation per se. In a traditional banking context, for example, the standard regulatory solution is not to require banks to match-fund their assets. Rather, governments often provide deposit insurance that limits the likelihood that depositors will panic. ${ }^{172}$

In other contexts, such as shadow banking, maturity transformation may well remain a real vulnerability. Because many shadow-banking sources of funding, such as short-term commercial paper, ${ }^{173}$ are not payable on demand-and thus not subject to the same type of "run" risk as traditional deposits-

168. See Christopher Condon, Reserve Primary Money Fund Falls Below $\$ 1$ a Share, BLOOMBERG (Sept. 16, 2008, 9:41 PM), http://www.bloomberg.com/ apps/news?pid=newsarchive\&sid=a5O2y1go1GRU.

169. See Jeffrey N. Gordon \& Christopher M. Gandia, Money Market Funds Run Risk: Will Floating Net Asset Value Fix the Problem?, 2014 Colum. Bus. L. REV. 313, 317 (also noting that the money-market mutual funds were unable to secure short-term credit to meet the sudden demand). To mitigate potential systemic consequences, the U.S. government stepped in to guarantee money-market mutual fund share prices, thereby calming investors and quelling the run.

170. See, e.g., Nouriel Roubini, Liquidity/Rollover Risk on US Assets? A Nightmare Hard Landing Scenario for the US $\$$ and US Bond Market, ECONOMONITOR (Dec. 21, 2004), http://www.economonitor.com/nouriel/2004/ 12/21/liquidityrollover-risk-on-us-assets-a-nightmare-hard-landing-scenario -for-the-us-and-the-us-bond-market/ (explaining that it is much less expensive to finance short-term debt than longer-term debt).

171. Id.

172. See, e.g., Douglas W. Diamond \& Philip H. Dybvig, Banking Theory, Deposit Insurance, and Bank Regulation, 59 J. BUS. 55, 63-64 (1986) (analyzing optimal contracts that prevent bank runs and observing that government provision of deposit insurance can produce superior contracts).

173. See supra note 163 and accompanying text. 
deposit insurance is not a solution. ${ }^{174}$ Other regulatory solutions are likely to be imperfect. ${ }^{175}$ The liquidity default risk that inevitably remains can trigger systemic shocks. Indeed, the failure of pre-financial-crisis regulation to adequately address liquidity default risk resulting from shadow banking's maturity transformation "is widely believed to have contributed to the buildup of risks in the financial system in the period leading up to" that crisis. $^{176}$

Notwithstanding the view of theorists, maturity transformation is not the only source of financial failure. ${ }^{177} \mathrm{I}$ next discuss additional vulnerabilities of the financial system that can trigger systemic shocks.

Responsibility Failure. Another structural vulnerability of the financial system that can trigger systemic shocks is the system's failure to internalize harm, which can motivate irresponsible conduct. A market participant may well decide to engage in a risky but profitable transaction, even though doing so could increase systemic risk, because much of the harm from a possible systemic collapse would be externalized onto other

174. Even if it were otherwise a solution, deposit insurance would not be as appropriate for shadow banks as it is for individual depositors; the latter are less capable of monitoring financial risk because they have less sophistication, and their investments individually may not merit the monitoring cost. Gerard Caprio, Jr., Bank Regulation: The Case of the Missing Model, in SEQUENCING? FinANCIAL StRATEGIES FOR DEveloping CounTRIES 10 (Alison Harwood \& Bruce L.R. Smith eds., 1996).

175. Depending on how it is designed, regulation protecting the financial system against maturity-transformation risk can increase moral hazard, which in turn can motivate risky actions by shadow banks. For example, regulation that protects the shadow-bank issuer of short-term securities against its own risky actions would almost certainly increase moral hazard. Regulation that limits incentives for shadow banks to engage in maturity transformation-such as imposing higher capital requirements on firms that engage in maturity transformation-would reduce moral hazard but would also reduce the economic efficiency achieved by maturity transformation. See supra notes 170-71 and accompanying text. A possible compromise might be regulation that protects not individual shadow banks but the overall markets for shortterm securities, such as the CPFF put into place by the U.S. Federal Reserve during the financial crisis to protect the commercial paper market. See infra notes 263-65 and accompanying text.

176. Anabtawi \& Schwarcz, supra note 11.

177. Cf. supra note 157 and accompanying text (observing that illiquidity is the fundamental source of financial failure). Although some might try to argue that the vulnerabilities discussed below are problematic only if they lead to liquidity, that would be incorrect; those vulnerabilities will also be problematic if they lead to insolvency). 
market participants as well as onto ordinary citizens impacted by an economic collapse. ${ }^{178}$

Although regulation can theoretically require all harm to be internalized, ${ }^{179}$ such a requirement may not be politically or pragmatically feasible. In the United States, for example, tort law focuses on internalizing externalities by empowering injured third parties to sue for harm. To be successful, however, plaintiffs normally must show their harm to be a causal and foreseeable consequence of the tortfeasor's actions. Systemic harm, however, is caused indirectly and affects a wide range of third parties in unpredictable ways. ${ }^{180}$

This vulnerability ${ }^{181}$ is exacerbated by the longstanding corporate law regime of limited liability. This is especially problematic for the small and decentralized firms (such as hedge funds and private equity firms) that dominate the shadowbanking sector, in which equity investors tend to be active managers. ${ }^{182}$ Limited liability gives these investor-managers strong incentives to take risks that could generate out-size personal profits, even if that increases the firm's chance of failure; because shadow-banking firms not only engage in financial intermediation on which the real economy is dependent but also are highly interconnected with traditional banks, their failure is likely to have systemic consequences. ${ }^{183}$

At least for shadow-banking firms subject to this type of conflict, limited liability should ideally be redesigned to better align investor incentives with societal interests. One approach might be to impose multiple-for example, double-liability, such that an equity investor-manager is liable to lose its investment plus an amount equal to its investment. ${ }^{184} \mathrm{I}$ have ar-

178. See supra notes $94-95$ and accompanying text.

179. See infra notes 257-62 and accompanying text (arguing that systemically risky firms should be required to internalize at least part of their harm by contributing to a systemic risk fund, which would provide liquidity as needed to stabilize those firms).

180. See supra notes 94 and accompanying text.

181. That is, the financial system's failure to internalize harm, which can motivate irresponsible conduct.

182. See Steven L. Schwarcz, The Governance Structure of Shadow Banking: Rethinking Assumptions About Limited Liability, 90 NOTRE DAME L. REV. $1,1-2$ (2014).

183. Id. at $2,17-18$.

184. See id. at 22-27, 29-30 (analyzing how limited liability should be redesigned). Annex 1 to that article summarizes the recommendations (which are qualified by the analysis in Part III). Among other things, limited liability should be increased for investor-managers of firms that operate in the shadow- 
gued elsewhere that this approach, even if applied only to investor-managers with the power to "control" their shadowbanking firms, should help to align incentives while minimizing investor risk aversion and monitoring costs. ${ }^{185}$

It is unclear, though, whether that or any other redesign of limited liability would (at least currently) be politically feasible, especially given the longstanding history of limited liability and the argument that it can benefit society by encouraging equity investment. ${ }^{186}$ This creates an irony of sorts: that regulation to improve microeconomic goals (limiting investor liability to encourage equity investment) can impair macroeconomic goals (limiting systemic risk-taking).

Other Structural Vulnerabilities that Can Trigger Systemic Shocks. Regulation cannot, therefore, realistically eliminate the foregoing triggers of systemic shocks. As explained below, the very nature of the financial system subjects it to other structural vulnerabilities that cannot be regulated away.

Because the financial system exhibits the characteristics of - and effectively comprises-a high-risk system that is susceptible to "normal accidents," therefore cannot eliminate, all the triggers of systemic shocks. ${ }^{188}$ The financial system is such a high-risk system because it has "interactive complexity" and "tight coupling." ${ }^{\text {, }}$ It has interactive complexity insofar as it is comprised of firms

banking system, i.e., equity investors who also have significant power to control those firms' actions. To minimize discouraging investment, the redesign should apply only to the subset of those equity investors who are entitled to a significant share of their firm's profits, since they are the ones who have strong incentives to take risks with their firms. The amount of the increase in limited liability should be sufficient to motivate investor-managers to monitor and guard against systemic risk, but not so great as to unduly discourage investment. This could be done by setting a cap on liability, such as restricting liability to a small multiple of the original investment. Recent scholarship suggests that double liability might represent a good balance. To solve the collective action problem of cross-border capital flight, federal law, rather than state law, could be used to increase limited liability in the United States. Some form of cross-border cooperation would also be needed to help mitigate the problem of international capital flight. See id. at 29-30.

185. Id. at 23 .

186. See id. at $4-9,13$.

187. For an analysis of normal accident theory, see CHARLES PERROW, NORMAL ACCIDENTS: LIVING WITH HIGH-RISK TECHNOLOGIES 18 (1999).

188. Cf. Awrey et al., supra note 36, at 1 (contending that absent information costs and uncertainty, market participants would be able to write contracts that allocate risk in every potential future state of the world, thereby ex ante addressing potential future liquidity problems).

189. Schwarcz, Regulating Complexity, supra note 87, at 214-15. 
and markets that are interactive and operate with incomplete information. ${ }^{190}$ Participants within the financial system are not fully aware of either the characteristics of the financial instruments that others in the system hold or the topology of the network that describes the system's structure. ${ }^{191}$ This creates uncertainty, making it difficult to ascertain the vulnerabilities of individual firms and markets to external shocks. ${ }^{192}$ That difficulty, in turn, can lead to unanticipated failures. ${ }^{193}$

The financial system also increasingly exhibits the characteristic of tight coupling ${ }^{194}$ because the failure by a firm or market can rapidly propagate throughout the financial system in various ways. Thus, technological innovation, such as highspeed computerized algorithmic trading technologies, has accelerated the speed with which local shocks can travel through the financial system. ${ }^{195}$ And shadow banking-the disintermediation of corporate finance, bypassing traditional bank intermediation (e.g., bank lending) between the sources of funds (essentially the capital and other financial markets) and business firms that need funds to operate-is increasing the channels for propagation of the failures, as explained below.

Another reason why regulators cannot realistically eliminate all of the triggers of systemic shocks is that certain market failures that are the subject of imperfect microprudential regulation could even trigger systemic failures. ${ }^{196}$ Information failure is classically seen, for example, as the source of bank

190. Anabtawi \& Schwarcz, Regulating Systemic Risk, supra note 63, at $1371 \&$ n.86, 1393.

191. Id. at $1393-94$.

192. Anabtawi \& Schwarcz, supra note 11, at 94 (citing Michael J. Naylor et al., A Network Theory of Financial Cascades 5 (July 23, 2008) (unpublished manuscript), http://papers.ssrn.com/sol3/papers.cfm?abstract_id=1184604 (concluding that the impact of any disturbance to the financial system cannot be understood without examining both the characteristics of individual nodes and the entire topology of the financial system)).

193. Id. Systemic shocks can also be triggered by financial panics, yet it is impossible to identify all the causes of panics.

194. Id. at 93 (citing PERROW, supra note 187, at 17-18).

195. See Schwarcz, Regulating Complexity, supra note 87, at 215, 232.

196. See, e.g., supra note 52 (providing an example of a microprudential regulatory failure that could have systemic consequences). Professors Jeffery Gordon and Colin Mayer additionally argue that cross-border harmonization of microprudential regulation is "potentially harmful for the cause of systemic stability for international finance." Jeffrey Gordon \& Colin Mayer, "The Micro, Macro and International Design of Financial Regulation" 21 (Mar. 28, 2012) (unpublished manuscript), http://papers.ssrn.com/sol3/papers.cfm?abstract_ id=2047436. 
runs and illiquidity. ${ }^{197}$ Information failure, principal-agent failure, and incentive failure could, individually or in combination, cause one or more large financial firms to overinvest, leading to bankruptcy; the bankruptcy of a large, interconnected financial firm could lead to a systemic collapse.

Similarly, rationality failure could cause the prices of securities in a large financial market to collapse. In 2008, for example, the realization that some investment-grade-rated mortgage-backed securities (MBS) were defaulting or being downgraded caused investors to panic. They lost faith in ratings and dumped all types of rated debt securities, causing debt-market prices to plummet and (for a time) destroying those markets as a source of corporate financing. ${ }^{198}$ Investor panics can occur in other contexts, like investors in Greek sovereign bonds dumping not only those bonds but also the bonds of many other Euro-zone countries. ${ }^{199}$

There are additional reasons why regulators cannot realistically eliminate all of the triggers of systemic shocks. Economists sometimes argue that systemic problems are inevitable because it is impossible to monitor everything in the financial system. ${ }^{200}$ Policymakers sometimes note that we often lack empirical evidence on regulatory cause and effect. Consider, for example, the special protections given to creditors in derivatives transactions under bankruptcy and insolvency law. These protections, which are claimed to be necessary to mitigate sys-

197. Cf. Douglas W. Diamond \& Philip H. Dybvig, Bank Runs, Deposit Insurance, and Liquidity, 91 J. POL. ECON. 401, 404 (1983) (using the DiamondDybvig model to explain bank runs as a form of undesirable equilibrium triggered by expectations based on incomplete information, in which depositors (sometimes irrationally) expect the bank to fail, thereby causing its failure); $c f$. Awrey et al., supra note 36, at 1 (arguing that where market participants are driven by liquidity constraints to sell assets into markets characterized by high information costs and/or uncertainty, the resulting realizations may be insufficient to cover their liabilities). Information failures arguably are only part of the cause of bank runs, however; even if an information failure initiates a run on a bank, depositors with perfect information face the collective action problem that they may have to join the run in order to avoid losing the grab race. See Steven L. Schwarcz, Ring-Fencing, 87 S. CAL. L. REV. 69, 91 (2013) [hereinafter Schwarcz, Ring-Fencing].

198. Richard G. Anderson \& Charles S. Gascon, The Commercial Paper Market, the Fed, and the 2007-2009 Financial Crisis, 91 FED. RES. BANK ST. LOUIS REV. 589, 602-05 (2009).

199. See Eichengreen, supra note 28 , at 5 .

200. See Eugene N. White, Professor of Econ., Rutgers Univ., Address at Chatham House Conference: Regulatory Coherence and the Future of Finance: Five Years After the Crash of 2008 (Dec. 6, 2013). 
temic risk, ${ }^{201}$ not only are arguably the most important example of macroprudential regulation in the United States but also serve as "an important precedent" for macroprudential regulation worldwide. ${ }^{202}$ At least in part, however, these protections are a path-dependent outcome of decades of sustained industry pressure on Congress to exempt the derivatives market from the reach of bankruptcy law. ${ }^{203}$ Although the earliest such protection lacked any empirical evidence of efficacy to mitigate systemic risk, once enacted as law it served as precedent for subsequent broader protections. ${ }^{204}$ Recent research suggests, however, that these protections can have unintended adverse consequences, possibly even increasing systemic risk. ${ }^{205}$ Professors Franklin Edwards and Edward Morrison argue, for example, that certain of these protections can trigger the equivalent of a bank run. ${ }^{206}$

It, therefore, is virtually certain that the financial system will face systemic shocks from time to time. Any

201. See, e.g., Steven L. Schwarcz \& Ori Sharon, The Bankruptcy-Law Safe Harbor for Derivatives: A Path-Dependence Analysis, 71 WASH. \& LEE L. REV. 1715, 1724-36 (2014) (explaining the history of these protections); Stephen D. Adams, Derivatives Safe Harbors in Bankruptcy and Dodd Frank: A Structural Analysis 9-10 (Mar. 3, 2014) (unpublished manuscript) http://ssrn.com/ abstract=2348828 (discussing that systemic risk has been central to justifying these protections and noting both the unanimity and vagueness of the discussions).

202. Schwarcz \& Sharon, supra note 201 .

203. Id.

204. Id. Overreliance on this precedent was almost certainly fostered by both the complexity of derivatives and uncertainty over how systemic risk is created and transmitted. Being concerned about systemic risk, members of Congress tended to see what they expected to see, the expectation in this case being driven by powerful derivatives-industry lobbying pressure. From a public choice standpoint, no powerful interest groups presented Congress with opposing views. Id.

205. Id.; see also DAVID SkEEL, THE NEW FINANCIAL DEAL: UNDERSTANDING THE DODD-FRANK ACT AND ITS (UNINTENDED) CONSEQUENCES 135 (2011); Franklin R. Edwards \& Edward R. Morrison, Derivatives and the Bankruptcy Code: Why the Special Treatment?, 22 YALE J. ON REG. 91, 95 (2005); Bryan G. Faubus, Narrowing the Bankruptcy Safe Harbor for Derivatives to Combat Systemic Risk, 59 DUKE L.J. 801, 828-29 (2010); Stephen J. Lubben, Derivatives and Bankruptcy: The Flawed Case for Special Treatment, 12 U. PA. J. Bus. L. 61, 75 (2009); Stephen J. Lubben, Repeal the Safe Harbor, 18 AM. BANKR. InST. L. REV. 319, 331 (2010); Mark J. Roe, The Derivatives Market's Payment Priorities As Financial Crisis Accelerator, 63 STAN. L. REV. 539, 561 (2011); Steven L. Schwarcz, Derivatives and Collateral: Balancing Remedies and Systemic Risk, 2015 U. ILL. L. REV. 699, 713.

206. Edwards \& Morrison, supra note 205, at 101 (discussing the possible unintended harm of unrestricted close-out netting). 
macroprudential regulatory framework should therefore be designed to also act ex post, after a systemic shock is triggered, by breaking the transmission of the shock and limiting its impact. ${ }^{207}$ This approach also accords with chaos theory, which addresses the problem of inevitable systemic shocks in complex engineering systems. The most successful (complex) systems are those in which the consequences of failures are limited. In engineering design, for example, decoupling systems through modularity helps to reduce the chance that a failure in one part of the system will systemically trigger a failure in another part. I have separately argued that chaos theory should apply equally to the problem of inevitable systemic shocks in the financial system. $^{20}$

The analysis next examines how macroprudential regulation could break the transmission of systemic shocks and limit their impact. This analysis will be partly informed by three factors that the International Monetary Fund (IMF) and the international Financial Stability Board (FSB) have identified as determinants of systemic risk: interconnectedness, size, and substitutability. ${ }^{209}$ In reality, these factors relate not to vulnerability but to contagion and the impact of contagion-or in the language of Part III.B, the transmission of systemic shocks and their impact. For example, interconnectedness is a contagion factor, facilitating transmission of systemic shocks. Size goes both to transmission and impact: the larger the size of the failure (other things being equal), the wider its transmission and impact. Substitutability goes to impact. These factors implicitly assume that the financial system is subject to vulnerabilities that could trigger systemic shocks; I have addressed those vulnerabilities in Part III.B.1, above. ${ }^{210}$

207. See supra note 154 and accompanying text.

208. See Schwarcz, Regulating Complexity, supra note 87, at 248-49 (focusing on the aspect of chaos theory regarding deterministic chaos in dynamic systems, which recognizes that the more complex the system, the more likely it is that failures will occur).

209. See, e.g., InT'L MONETARY Fund, GUIDANCE to ASSESS THE SySTEMIC IMPORTANCE OF FINANCIAL INSTITUTIONS, MARKETS AND INSTRUMENTS: INITIAL CONSIDERATIONS (2009), https://www.bis.org/publ/othp07.pdf. The IMF also takes into account cross-jurisdictional activity and complexity. See INT'L MONETARY FUnd, MACROPRUDENTIAL POLICY TOOLS AND FRAMEWORKS 12 (2011). I take those factors into account throughout this Article's analysis.

210. See supra notes 155-205 and accompanying text. 


\section{Regulation To Break the Transmission of Systemic Shocks}

To break the transmission of systemic failures in the financial system would require that the transmission mechanisms all be identifiable. It is probably not feasible, however, to identify all those mechanisms in advance. ${ }^{211}$ Regulators are nonetheless experimenting with this approach, especially with ringfencing. ${ }^{212}$

When used as a form of financial regulation, ring-fencing can best be understood as legally deconstructing a firm in order to more optimally reallocate and reduce risk. ${ }^{213}$ The deconstruction could occur in various ways. For example, the firm could be made more internally viable, such as by separating risky assets from the firm and preventing the firm from engaging in risky activities or investing in risky assets. ${ }^{214}$ The firm could also be protected from external risks, such as ensuring that the firm is able to operate on a stand-alone basis even if its affiliates fail and insulating the firm from third-party claims, involuntary bankruptcy, and affiliate abuse. ${ }^{215}$ The examples of insulating the firm epitomize breaking the transmission of shocks.

Ring-fencing's reallocation of risk raises important normative questions about when, and how, it should be used as an economic regulatory tool. For example, ring-fencing is often considered to help protect publicly essential activities performed by utility companies and sometimes considered to help protect publicly beneficial activities performed by banks. The latter is exemplified by the ring-fencing used under the Glass-

211. Anabtawi \& Schwarcz, Regulating Systemic Risk, supra note 63, at 1404.

212. Another way that regulation could attempt to break the transmission of systemic shocks is by implementing strategies to wind down, or otherwise resolve, failing systemically important firms in a way that minimally transmits the shocks. See Anabtawi \& Schwarcz, supra note 11, at 117. For example, the Dodd-Frank Act requires banks and other financial institutions deemed systemically important to annually submit a resolution plan (the socalled "living will" requirement) explaining how the firm could liquidate in an orderly manner to help reduce systemic impact. $I d$. at 116 . A related approach is to require some portion of a systemically important financial firm's debt to be held in the form of the so-called "contingent capital," which would automatically convert to equity upon the occurrence of certain specified events to prevent the firm's failure. Id. at 117; cf. infra notes 234-36 and accompanying text (discussing that approach).

213. See Schwarcz, Ring-Fencing, supra note 197, at 72.

214. Id. at 108 .

215. Id. 
Steagall Act ${ }^{216}$ and proposed in the final report of the U.K. Independent Commission on Banking (often called the Vickers Report). ${ }^{217}$ The Vickers Report recommends a limited form of separation intended to protect the "basic banking services of safeguarding retail deposits, operating secure payments systems, efficiently channeling savings to productive investments [i.e., making loans], and managing financial risk."218

From a cost-benefit standpoint, ring-fencing is highly likely to be appropriate to help protect the publicly essential activities performed by utility companies, such as providing power, clean water, and communications. ${ }^{219}$ Not only are those services necessary, but also the utility company, normally being a monopoly, is the only entity able to provide the services. Ring-fencing utility companies against risk helps assure the continuity of their services.

It is less certain, though, that ring-fencing should be used to help protect other publicly beneficial activities. For example, even if the public services provided by banks were as important as those provided by public utilities, ${ }^{220}$ the need to ring-fence banks would not be as strong as the need to ring-fence public utilities. This is because the market for banking services is competitive. If some risky banks become unable to provide services, other banks should be able to provide substitute services-and the more substitutable something is, the less systemically risky would be its loss. ${ }^{221}$ It therefore is uncertain

216. In the United States, the Glass-Steagall Act (which has since been revoked) had created a separation between commercial and investment banking-the former including deposit taking and lending, the latter including securities underwriting and investing. Banking Act of 1933, Pub. L. No. 73-66, 48 Stat. 162 (repealed 1999).

217. See INDEP. COMM'N ON BANKING, FINAL REPORT: RECOMMENDATIONS (2011), http://www.ecgi.org/documents/icb_final_report_12sep2011.pdf [hereinafter VICKERS REPORT]. Although I provided input for this report in a November 12, 2010 meeting at All Souls College, University of Oxford, with Commission Chairman Sir John Vickers and other members of the Commission's secretariat, I did not suggest the ring-fencing procedure that the report eventually adopted.

218. Id. at 7. Ring-fencing is more of a microprudential than macroprudential approach to the extent its focus is more on protecting retail banking activities rather than on preventing systemic collapse. See Schwarcz, Ring-Fencing, supra note 197, at 101.

219. Schwarcz, Ring-Fencing, supra note 197, at 105.

220. I use this example solely as an illustration. I do not suggest that the public services provided by banks are as important as those provided by public utilities.

221. See supra note 209 and accompanying text (discussing substitutability 
whether the benefits of ring-fencing banks would exceed its costs.

Because regulation cannot-and perhaps should not attempt to $^{222}$-completely break the transmission of systemic shocks, we need to also find ways to limit their impact. Trying to stabilize systemically important firms and financial markets impacted by the shocks could accomplish this. ${ }^{223}$

\section{Regulation To Limit the Impact of Systemic Shocks}

There are at least three ways that regulation could attempt to stabilize systemically important firms and financial markets impacted by shocks: by requiring those firms and markets to be more internally robust; by providing appropriate liquidity to those firms and markets; and, at least for firms, by providing for their resolution in ways that minimally impact markets and other firms.

Requiring Firms and Markets To Be More Internally Robust. Regulation could help to stabilize systemically important firms and markets by requiring them to be more internally robust. ${ }^{224}$ This could be accomplished in various ways. First, consider systemically important firms.

Financial regulation has long focused on requiring traditional deposit-taking banks to be robust, usually through firmspecific capital and solvency requirements. ${ }^{225}$ Since the financial crisis, the United States, the European Union, and other jurisdictions are beginning to also subject "systemically im-

as one of three primary factors by which to assess systemic risk). In the United Kingdom, the market for banking services appears to be less competitive than in the United States. VICKERS REPORT, supra note 217, at 16; text accompanying supra note 217 (reporting that the top four U.K. banks account for seventy-seven percent of personal bank accounts and eighty-five percent of lending to small and medium sized enterprises). To that extent, the case for ring-fencing U.K. banks would be more compelling than the case for ringfencing U.S. banks. See Schwarcz, Ring-Fencing, supra note 197, at 104-05.

222. As discussed above, the costs of regulation that seeks to completely break the transmission of systemic shocks can exceed the benefits.

223. See Anabtawi \& Schwarcz, supra note 11, at 102.

224. Although I refer to regulation requiring firms to become more robust as ex post (in the sense that more robust firms can better withstand a systemic shock), such regulation could also be viewed as ex ante in the sense that robust firms are less likely to fail and thereby trigger a systemic shock.

225. See Schwarcz, Systemic Risk, supra note 24, at 210 ("Historically, regulation of systemic risk has focused largely on preventing bank failure."). 
portant" shadow banks to a range of capital, solvency, and similar requirements. ${ }^{226}$

Functional regulation could, in theory, likewise impose capital and solvency requirements on systemically important shadow banks. But it need not impose those requirements if it otherwise stabilizes those firms, such as by providing liquidity if and when needed to protect the financial system's network functions. ${ }^{227}$ This insight enables functional macroprudential regulation to be much more flexible than traditional macroprudential regulation.

Traditional macroprudential regulation is inflexible because it implicitly, and confusingly, mixes microprudential and macroprudential goals. The microprudential goal is to assure that traditional and shadow banks can continue operating. ${ }^{228}$ By subjecting traditional banks and systemically important shadow banks to rigorous capital, solvency, and similar requirements (to assure that they can continue operating), that microprudential goal inadvertently becomes a goal of macroprudential regulation.

The flaw in this mixed approach is that macroprudential regulation's only goal should be to protect the financial system's overall capacity to function as a network. ${ }^{229}$ Macroprudential regulation need not, therefore, impose capital or solvency requirements on individual firms-even shadow banks that are systemically important—so long as it otherwise achieves that goal (such as by providing liquidity ${ }^{230}$ ). This regulatory flexibility is important because capital and solvency requirements do not always efficiently reduce systemic risk. ${ }^{231}$

226. In the United States, for example, Dodd-Frank Act $\S 115(b) \& 165(\mathrm{i})$, 12 U.S.C. $§ 5325$ (2012), direct the Federal Reserve to set "prudential" capital standards for certain large financial firms, including a maximum debt-toequity ratio of 15:1. Id. $\S 165(\mathrm{j})$. On January 1, 2014, the so-called CRD (Capital Requirements Directive) IV package took effect in the European Union, imposing Basel III-type capital requirements on certain shadow-banking entities. Council Directive 2013/36, art. 12, 2013 O.J. (L 176) 355 (EU), http://eur -lex.europa.eu/legal-content/EN/TXT/?uri=CELEX:32013L0036.

227. See infra notes 254-65 and accompanying text (discussing liquidity).

228. Cf. supra notes 18-19 and accompanying text (defining microprudential regulation as regulation of the financial system's components-in this case, its firms).

229. See supra notes 22-23 and accompanying text.

230. See infra notes 254-61 and accompanying text.

231. Cf. Haldane, supra note 60 , at 5 (observing that in "an uncertain [economic] environment, where statistical probabilities are unknown," using "[p]robabilistic weights from the past" to set regulatory requirements is un- 
Reducing a shadow bank's leverage, for example, can certainly enable the firm to withstand economic shocks and reduce its chance of failure. The Basel capital requirements, however, did not prevent the many failures of traditional banks resulting from the financial crisis. ${ }^{232}$ And setting regulatory limits on leverage could also backfire. Some leverage is good, and there is no optimal across-the-board amount of leverage that is right for every firm. ${ }^{233}$

Other potential approaches to make traditional banks and systemically important shadow banks more internally robust are also open to question. One highly touted approach is to require at least some portion of the firm's debt to be in the form of so-called "contingent capital." ${ }^{34}$ Contingent capital debt would automatically convert to equity upon the occurrence of pre-agreed events. Requiring contingent capital is therefore effectively like requiring a pre-planned debt restructuring or workout. But it is unclear if regulatory-imposed contingent capital would be efficient. ${ }^{235}$ If contingent capital is a good idea,

suitable because the past "may be a fragile guide to the future").

232. See, e.g., id. at 7 (observing that the financial crisis "exposed gaping holes in the" Basel capital requirements). Haldane also observes that "serious questions have been expressed about the opacity of the Basel risk weights" and that the Basel capital requirements' "complexity also raises serious concerns about the robustness of [its] regulatory framework given its degree of over-parameterisation." Id. at 8 (listing hundreds of U.S. banks which have failed since October 2010); see also Failed Bank List, FDIC, https://www .fdic.gov/bank/individual/failed/banklist.html (last visited Mar. 11, 2016); Looking Back at Bank Failure Rates, FORBES (Mar. 25, 2013), http://www .forbes.com/sites/moneybuilder/2013/03/25/looking-back-at-bank-failure-rates/ (describing the location of and the number of bank failures each year).

233. See Schwarcz, Systemic Risk, supra note 24, at 224; cf. Pistor, supra note 52, at 46 (observing that "imposing capital or reserve requirements can push market participants to find ways [including the use of derivatives] to formally comply while making sure that their disposable assets are in fact not much curtailed," thereby creating "additional sources of liquidity risk [that can] remain[] largely unrecognized by financial intermediaries and regulators alike"). My analysis in the text above observes that an optimum leverage may not exist. That leaves open, however, the possibility that a maximum leverage may exist, i.e., that there may be an amount of leverage that is nearly always too high.

234. See, e.g., John C. Coffee, Jr., Systemic Risk After Dodd-Frank: Contingent Capital and the Need for Regulatory Strategies Beyond Oversight, 111 COLUM. L. REV. 795, 806-07 (2011) (explaining "contingent capital" as a system where debt securities gradually convert into equity securities).

235. As of July 2011, the Basel Committee has determined that systemically important financial firms will only be allowed to meet their additional loss absorbency requirement with common equity Tier 1 capital, not contingent capital. The Basel Committee will, however, "continue to review contingent capital, and support the use of contingent capital to meet higher national loss 
markets themselves should implement it, but there is no evidence of that implementation (nor is there evidence of market failures impeding that implementation) ${ }^{236}$ Regulatory-imposed contingent capital might also have unforeseen consequences. For example, automatic conversions of debt claims to equity interests might create counterparty risk by reducing the value of firms holding those claims.

Similarly, ring-fencing can help to make traditional banks and systemically important shadow banks more internally viable-and thus more robust-by preventing the firm from engaging in risky activities and investing in risky assets. ${ }^{237}$ The so-called Volcker Rule, which imposes limitations on proprietary trading in order to prevent traditional banks and systemically important shadow banks from investing in risky assets, ${ }^{238}$ epitomizes this approach. ${ }^{239}$ The merits of the Volcker Rule, however, remain controversial and untested. ${ }^{240}$ Some are skeptical of any rule that paternalistically substitutes a blanket regulatory prescription for a sophisticated firm's own business judgment. ${ }^{241}$ On the other hand, the fact that limited-liability firms may rationally decide to engage in profitable transactions

absorbency requirements than the global requirement, as high-trigger contingent capital could help absorb losses on a going concern basis." BANK FOR INT'L SETTLEMENTS, GLOBAL SySTEMICALly IMPORTANT BANKS: ASSESSMENT METHODOLOGY AND THE ADDITIONAL LOSS ABSORBENCY REQUIREMENT 19-20 (Nov. 2011), http://www.bis.org/publ/bcbs207.pdf.

236. But cf. E-mail from Klingman, supra note 115 (arguing that because of "the perverse incentives that exist in banking, ... [m] arkets would likely not implement many things considered valuable in banking").

237. See supra note 214 and accompanying text. Ring-fencing is also used to ensure that a firm is able to operate on a stand-alone basis, even if its affiliates fail. See supra note 215 and accompanying text.

238. See Dodd-Frank Act, Pub. L. No. 111-203 sec. 619, § 13 (2010).

239. The primary goal of the Volcker Rule, however, is to prevent losses that could trigger the systemic collapse of those firms. Senator Jeff Merkley \& Senator Carl Levin, The Dodd-Frank Act Restrictions on Proprietary Trading and Conflicts of Interest: New Tools To Address Evolving Threats, 48 HARV. J. ON LEGIS. 515, 531-32 (2011).

240. Reducing limited liability could make the Volcker Rule redundant, by exposing investors to more of the costs associated with their firm's risk-taking activities and thereby reducing their incentives for risk-taking. See supra notes 181-86 and accompanying text.

241. Moody's has warned, for example, that a leaked early draft of interagency rules implementing the Volcker Rule would, if adopted, probably "diminish the flexibility and profitability of banks' valuable market-making operations and place them at a competitive disadvantage to firms not constrained by the rule." Edward Wyatt, Regulators To Set Forth Volcker Rule, N.Y. TIMES (Oct. 10, 2011) (quoting Moody's), http://www.nytimes.com/2011/10/11/ business/volcker-rule-to-take-shape-this-week.html. 
that increase systemic risk ${ }^{242}$ suggests that the Volcker Rule is not completely misguided. The Volcker Rule has not, however, been subjected to a rigorous cost-benefit analysis or compared to the costs and benefits of other regulatory approaches to mitigating systemic risk. ${ }^{243}$

The discussion above has focused on stabilizing firms by requiring them to be more internally robust. Regulation could similarly help to stabilize systemically important financial markets-which are now as much a part of the financial system as financial firms ${ }^{244}$-by requiring them also to be more internally robust. For example ${ }^{245}$ increased speed in data transmission is generally associated with market efficiency, ${ }^{246}$ but the extreme speeds at which algorithmic trading takes place creates a danger of market collapse. In 2010, the Dow Jones Industrial Average plunged nearly 1000 points in twenty minutes, precipitated by a trader executing an algorithm to sell approximately $\$ 4.1$ billion worth of stock market index futures contracts without regard to time or price. ${ }^{247}$ In response, the SEC adopted a universal circuit breaker rule ${ }^{248}$ to halt trading

242. See supra note 94 and accompanying text.

243. One might question whether the Volcker Rule is even amenable to a rigorous cost-benefit analysis. $C f$. E-mail from Klingman, supra note 115 (arguing that because the regulations implementing the Volcker Rule are confusing and somewhat vague, "any attempted [economic] analysis would likely have a chi-squared distribution so broad as to be meaningless").

244. See, e.g., Schwarcz, Systemic Risk, supra note 24, at 198-204; Interview by Charlie Rose with Mark Carney, Governor, Bank of England, on The Charlie Rose Show, Dec. 9, 2013 (transcript at 6) (quoting Carney as stating that " $[\mathrm{m}]$ onetary policy got itself into a cul-de-sac where it didn't take seriously financial markets").

245. Another example of regulation that could help to stabilize systemically important financial markets would be reducing tight coupling by suspending mark-to-market accounting requirements under appropriate conditions. See Anabtawi \& Schwarcz, supra note 11, at 117-22 (explaining appropriate times to apply the tight coupling reduction method).

246. See James Angel et al., Equity Trading in the 21st Century 5-6 (U. S. Cal. Marshall Sch. of Bus., Working Paper No. FBE 09-10, 2010), http:// papers.ssrn.com/sol3/papers.cfm?abstract_id=1584026 (arguing that highfrequency trading results in improved market quality); see also Matt Samelson, Answering the Question of High-Frequency Trading, SEC. INDUS. NEwS, May 3, 2010, at 23 (arguing that high-frequency trading has improved execution quality and reduced short-term volatility in large cap U.S. equities).

247. Findings Regarding the Market Events of May 6, 2010, CoMmodiTy FUTURES TRADING COMM'N \& SEC. \& EXCH. COMM'N 14 (Sept. 30, 2010), http:// www.sec.gov/news/studies/2010/marketevents-report.pdf.

248. A circuit breaker is a procedure for temporarily halting trading when a severe market downturn threatens to exhaust available liquidity. Investor Bulletin: Measures to Address Market Volatility, U.S. SEC. \& ExCH. CoMm'N, 
of an individual security across all exchanges for five minutes if its price deviates by ten percent or more over a five-minute period. ${ }^{249}$ By affecting all markets in which the security trades, a universal circuit breaker rule goes beyond traditional circuit breakers, which are used only in individual markets. ${ }^{250}$ Although some parties commented that the SEC rule could exacerbate price volatility by inducing panic, ${ }^{251}$ most commentators believe that a universal circuit breaker will reduce excess market volatility. ${ }^{252}$

Providing Liquidity to Firms and Markets. Regulation could also help to stabilize firms and markets by providing appropriate liquidity. ${ }^{253}$ Liquidity has traditionally been used, especially by government central banks, to help prevent banks from defaulting. ${ }^{254}$ Ensuring liquidity to stabilize systemically important firms could follow this pattern, except that the source of the liquidity could at least be partly privatized by taxing those firms to create a systemic risk fund. ${ }^{255}$ As explained below, that would not only internalize costs but also help to al-

http://www.sec.gov/answers/circuit.htm (last updated Mar. 11, 2016).

249. Order Granting Accelerated Approval to Proposed Rule Change to Amend FINRA Rule 6121, 75 Fed. Reg. 34,183 (June 16, 2010). The fiveminute pause was intended to give traders enough time to recognize and respond to price disparities.

250. Circuit breakers are also criticized as giving an unfair advantage to market makers and sophisticated traders over individual investors. Frank Partnoy, Why Markets Crash and What Law Can Do About It, 61 U. PITT. L. REV. 741, 783 (2000); cf. Emilios Avgouleas, A New Framework for the Global Regulation of Short Sales: Why Prohibition Is Insufficient and Disclosure Insufficient, 15 STAN. J.L. BUS. \& FIN. 376, 416 (2010) (arguing that the circuit breaker rule takes into account both longer term price trends and levels of liquidity).

251. See Anabtawi \& Schwarcz, Regulating Systemic Risk, supra note 63, at 1400 n.208.

252. See $i d$.

253. This assumes a firm that is solvent but illiquid, so that liquidity would stave off a default. For an insolvent firm that is illiquid, liquidity may only provide temporary relief from default. Additional remedies would then be needed, such as a resolution mechanism that (like contingent capital) converts some debt to equity in order to make the firm solvent again. See supra note 234 and accompanying text.

254. Cf. Awrey et al., supra note 36, at 4 (observing that the only true lender of last resort is a market participant with no survival constraint and a theoretically unlimited supply of liquidity-which effectively means only sovereign states that control their own currency and are able to issue debt in that currency).

255. A government-imposed tax would be necessary because private market participants, even if they had the ability to do so, will intervene only where they perceive it to be in their best interests to do so. Id. 
lay the political concerns about moral hazard and taxpayer expense that led Congress, in the Dodd-Frank Act, to limit the Federal Reserve's power to provide emergency liquidity. ${ }^{256}$

The precedents for requiring the private sector to contribute funds to help internalize externalities include the U.S. Federal Deposit Insurance Corporation (FDIC), which requires member banks to contribute to a Deposit Insurance Fund to ensure that depositors of failed banks are repaid. ${ }^{257}$ Similarly, U.S. law requires each owner of a nuclear reactor to contribute monies to a fund to compensate for possible reactor accidents. ${ }^{258}$

In the systemic risk context, privatizing the source of liquidity would likewise help to internalize externalities by addressing the dilemma that market participants are economically motivated to create externalities that could have systemic consequences. ${ }^{259}$ The plan by certain European Union countries to impose a Financial Transactions Tax provides a real-world example of how the privatization could work. ${ }^{260}$ Privatization

256. The Dodd-Frank Act "circumscribed the ability of the Federal Reserve to act as lender of last resort to the same extent that it did during the financial crisis." Michael Fleming \& Asani Sarkar, The Failure Resolution of Lehman Brothers, 20 FRBNY ECON. POL'Y REV. 175, 178 (2014). That will virtually assure that the future bankruptcy of a systemically important firm will result in high creditor losses. Id.; cf. Anabtawi \& Schwarcz, supra note 11, at 130 (observing that by circumscribing that ability, the Dodd-Frank Act incorrectly "conflate[s] ex post regulation with indiscriminate bailouts and taxpayer expropriation [thereby] increasing the risk that that a systemically important financial firm or market will collapse, with systemic consequences"). This type of lender-of-last-resort, emergency orientated, activity is distinct from the Federal Reserve Bank's role in managing temporary shortages in liquidity. Through the "discount window," the Federal Reserve allows eligible banks to take short-term loans to help cure temporary liquidity failures. See generally Colleen Baker, The Federal Reserve As Last Resort, 46 U. MICH. J. L. REFORM 69, 83-84 (2012) (discussing reforms that aim to ensure "last resort" lending does not encourage excessive risk taking and mispricing).

257. See infra note 261.

258. Nuclear Insurance and Disaster Relief Funds, U.S. NUCLEAR REG. COMM'N, http://www.nrc.gov/reading-rm/doc-collections/fact-sheets/funds-fs .html (last updated Nov. 26, 2015).

259. Cf. Jeffrey N. Gordon \& Christopher Muller, Confronting Financial Crisis: Dodd-Frank's Dangers and the Case for a Systemic Emergency Insurance Fund, 28 YALE J. ON REG. 151, 156 (2011) (calling for a systemic emergency insurance fund that is funded by the financial industry).

260. Eleven member states of the European Union have agreed through enhanced cooperation to establish a Financial Transactions Tax (FTT). European Commission Press Release IP/13/15, Financial Transaction Tax Under Enhanced Cooperation: Commission Sets Out the Details (Feb. 14, 2013), http://europa.eu/rapid/press-release_IP-13-115_en.htm. The FTT seeks to internalize financial costs that would otherwise be borne by taxpayers. See European Commission Proposal for a Council Directive Implementing Enhanced 
would not only offset the cost to taxpayers of liquidity advances that are not repaid but also, if structured appropriately, ${ }^{261}$ should reduce moral hazard by discouraging fund contributors-including those that believe they are "too big to fail"from engaging in financially risky activities. ${ }^{262}$ The likelihood that systemically important firms will have to make additional contributions to the fund to replenish bailout monies should also motivate those firms to cross-monitor each other and thereby help control each other's risky behavior.

It is not enough to try to stabilize systemically important firms. Because financial markets can also be triggers and transmitters of systemic shocks, liquidity should be used to stabilize systemically important financial markets. ${ }^{263}$ For ex-

Cooperation in the Area of Financial Transaction Tax, at 2, COM (2013) $71 \mathrm{fi}$ nal (proposed Feb. 14, 2013), http://ec.europa.eu/taxation_customs/resources/ documents/taxation/ com_2013_71_en.pdf. The FTT is scheduled to take effect on January 1, 2016. See Rebecca Christie \& Jim Brunsden, EU FinancialTransaction Plans Turn to Derivatives, BlOOMBERG (May 23, 2014), http:// www.bloomberg.com/news/2014-05-23/eu-financial-transaction-tax-plans-turn -to-derivatives.html. In another possible example of privatization, the EU Bank Recovery and Resolution Directive, which enhances guidelines for the resolution of failing banks in a time of crisis, created a resolution fund aimed at providing medium-term bailouts (e.g., bridge loans and the purchase of specific assets) funded by the financial institutions themselves. See EUROPEAN COMMISSION, BAIL-IN TOOL: A COMPARATIVE ANALYSIS OF THE INSTITUTIONS' APPROACHES 2 (2013); see also European Commission, Memorandum MEMO/14/297, EU Bank Recovery and Resolution Directive (BRRD): Frequently Asked Questions (Apr. 15, 2014), http://europa.eu/rapid/press -release_MEMO-14-297_en.htm.

261. Privatized contributions to the systemic risk fund should be sized as a function, among other factors, of the contributor's financially risky activities. The actual mechanics of the sizing, however, could potentially raise questions: for example, how should the aggregate need for funding be estimated? How should funding be allocated among contributing firms, initially and over time?; which firms should be required to contribute?; and might it be possible to size a partial privatization that is onerous enough to mitigate moral hazard but yet small enough to make a systemic risk fund politically viable? There are also concerns that too large of a systemic risk fund, for example, might decrease efficiency by decreasing the amount of capital banks can use to invest. See EUROPEAN COMM'N, supra note 260, at 4 . In contrast, too small of a fund could prove to be procyclical by letting banks have too much capital and not enough of an insurance cushion. Cf. Adam Geršl \& Petr Jakubík, How Important Is the Adverse Feedback Loop for the Banking Sector?, 60 EKONOMICKÝ ČASOPIS 32,34 (2012).

262. Cf. Antonio E. Bernardo et al., A Model of Optimal Government Bailouts, BeRKEley PROGRAM L. \& ECON. 1, 4 (2011), https://escholarship .org/uc/item/8wv4p90c (arguing, inter alia, that an optimal bailout should be funded through a redistributive tax on healthy firms rather than an extraordinary tax on a rescued firm).

263. For the first proposal of utilizing liquidity to stabilize financial mar- 
ample, in response to the post-Lehman collapse of the commercial paper market, the U.S. Federal Reserve created the Commercial Paper Funding Facility (CPFF) to act as a lender of last resort for that market, with the goal of addressing "temporary liquidity distortions" by purchasing commercial paper from highly rated issuers that could not otherwise sell their paper. ${ }^{264}$ The CPFF helped to stabilize the commercial paper market. ${ }^{265}$

Resolving Firms in Ways that Minimally Impact Markets and Other Firms. Resolution mechanisms can also serve to mitigate the harmful consequences of the failure of systemically important firms impacted by shocks. If a firm is going to fail notwithstanding efforts to make it more internally robust and liquid, ${ }^{266}$ a fallback approach is to resolve the firm-i.e., reorganize or liquidate it in a way that mitigates harmful consequences. This is the classic approach to addressing troubled firms, embodied through bankruptcy and insolvency laws. ${ }^{267}$

Traditional bankruptcy and insolvency laws, like traditional financial regulation, focus almost exclusively on microprudential goals. For example, Section 1112 of the U.S. Bankruptcy Code directs the court to base the critical reorganization-versus-liquidation determination on "whichever is in the best interests of creditors and the [troubled firm's] estate," without consideration of systemic consequences. ${ }^{268}$ Even prior to

kets, see Schwarcz, Systemic Risk, supra note 24, at 225-30.

264. See Commercial Paper Funding Facility, FED. RESERVE, http://www .federalreserve.gov/monetarypolicy/cpff.htm (last visited Mar. 11, 2016) (describing the liquidity backstop to U.S. issuers of commercial paper from 20082010); see also TOBIAS ADRIAN ET AL., FED. RESERVE BANK OF N.Y. STAFF, REPORT NO. 423: THE FEDERAL RESERVE's COMMERCIAL PAPER FUNDING FACILITY (June 2010) (elaborating on the creation of the CPFF with reviews on the operation of the CPFF and discussion of the usage of the facility).

265. ADRIAN ET AL., supra note 264, at 27 ("The CPFF indeed had a stabilizing effect on the commercial paper market ....").

266. See supra notes 224-65 and accompanying text (discussing ways to make systemically important firms more internally robust and liquid).

267. See, e.g., 11 U.S.C ch. 7 \& 11 (2012) (providing for the liquidation or reorganization of troubled firms). Although the terms "bankruptcy" and "insolvency" are often used interchangeably, the former is more commonly used in the United States, where insolvency is not a condition of filing a voluntary petition for resolution. See 11 U.S.C. § 301.

268. See 11 U.S.C. $§ 1112$ (b) (2012); cf. Douglas G. Baird, Bankruptcy's Uncontested Axioms, 108 YALE L.J. 573, 580-81 (1998) (comparing the competing fundamental goals of U.S. bankruptcy law, which do not address systemic risk). 
the financial crisis, however, bankruptcy and insolvency laws sometimes took macroprudential goals into account. ${ }^{269}$

Since the financial crisis, resolution has become one of the primary regulatory approaches being taken worldwide to minimize systemic risk from firms impacted by shocks. The fact that regulators and lawyers have longstanding and extensive experience using resolution mechanisms to address troubled firms may account for the prevalence of this approach. Whatever explains its prevalence, however, governments are currently experimenting with a variety of resolution mechanisms, including providing for the orderly liquidation of troubled systemically important firms; ${ }^{270}$ requiring those firms to formally plan in advance how they could liquidate without systemic impact; ${ }^{271}$ providing for a so-called single-point-of-entry resolution by requiring those firms to effectively operate in holding company structures; ${ }^{272}$ requiring the so-called bail-in of those firm's owners and creditors; ${ }^{273}$ and analyzing whether bankruptcy law should operate differently for those firms. ${ }^{274}$ Governments and international organizations are also examining, for multina-

269. Certain provisions of the U.S. Bankruptcy Code addressing derivatives contracts, and parallel provisions in some foreign insolvency laws, were added in the past few decades with at least the political justification of minimizing systemic risk. See Schwarcz \& Sharon, supra note 201, at 1716-17, 1724-36.

270. See Dodd-Frank Act, Pub. L. No. 111-203, §§ 201-17 (2010); see also Commission Regulation 806/2014, Single Resolution Mechanism, 2014 O.J. (L 225) 1.

271. See Anabtawi \& Schwarcz, supra note 11, at 116 (discussing so-called "living wills").

272. See, e.g., Jeffrey N. Gordon \& Wolf-Georg Ring, Bank Resolution in European Banking Union: A Transatlantic Perspective on What It Would Take 2 (Colum. L. \& Econ. Working Paper, No. 465, 2014), http://papers .ssrn.com/sol3/papers.cfm?abstract_id=2361347 (arguing for single-point-ofentry bank resolution through mandated bank-holding-company structures in which lending is to the holding company-effectively structural subordination).

273. Contingent capital is often a part of the bail-in mechanism. Cf. supra notes 234-36 and accompanying text (discussing contingent capital, in which debt claims of a troubled firm are converted into equity interests).

274. See, e.g., Stephanie Massman, House Passes Financial Institution Bankruptcy Act, HARV. LAW ScH. BANKR. ROUNDTABLE (Dec. 9, 2014), http://blogs.law.harvard.edu/bankruptcyroundtable/2014/12/09/house-passes -financial-institution-bankruptcy-act (discussing legislation to amend the U.S. Bankruptcy Code to "better allow for the resolution of systemically important financial institutions"). 
tional systemically important troubled firms, how resolution mechanisms could be made to work across national borders. ${ }^{275}$

Resolution mechanisms are, of course, only one of the possible strategies to mitigate the harmful consequences of the failure of systemically important firms impacted by shocks. ${ }^{276}$ Equally limiting, resolution mechanisms do not even purport to stabilize systemically important markets impacted by shocks. Within these limits, however, the ongoing experimentation with a range of domestic and cross-border resolution mechanisms is consistent with this Article's functional approach.

\section{CONCLUSIONS}

How should we think about regulating a constantly changing financial system? Existing regulatory approaches suffer from two time-bound flaws. One flaw is obvious: politics and human nature make financial regulation overly reactive to past crises, thereby unduly pinning regulation to the past. Policymakers and regulators are aware of, and have been trying to address, that flaw.

This Article addresses a less obvious, but arguably more fundamental, flaw: financial regulation is normally tethered to the financial architecture, including the distinctive design and structure of financial firms and markets, in place when the regulation is promulgated. This flaw unduly pins regulation to the present. Financial regulation, however, must transcend that time-bound architecture because without continuous monitoring and updating - which rarely occurs because it is costly and subject to political interference-present-day regulation can quickly become outmoded.

That occurred in 2008 , for example, when the pre-crisis financial regulatory framework, which assumed the dominance of bank-intermediated funding, failed to adequately address a collapsing financial system in which the majority of funding had become non-bank intermediated. ${ }^{277}$ And it is beginning to

275. See, e.g., StEven L. SCHWARCZ ET AL., CTR. FOR INT'L GOVERNANCE INNOVATION, COMMENTS ON THE SEPTEMBER 29, 2014 FSB CONSUlTATIVE DOCUMENT, "CROSS-BORDER RECOGNITION OF RESOLUTION ACTION" (Dec. 2014), http://www.cigionline .org/sites/default/files/no.51.pdf.

276. Recall that other strategies include requiring systemically important firms and markets to be more internally robust and providing appropriate liquidity to those firms and markets. See supra notes 223-24 and accompanying text.

277. See supra notes 8-10 and accompanying text (discussing the advent of shadow banking). 
occur again. Spurred by the financial crisis, regulators are concentrating on identifying regulatory "tools" to fix specific perceived defects in the design and structure of today's financial firms and markets. Even assuming these tools would work today, they could, and if not recalibrated, almost certainly would, lose their utility over time-in which case, the tools could actually exacerbate financial problems. ${ }^{278}$

Financial regulation should embrace change, this Article demonstrates, by also focusing on protecting the ongoing functions of the financial system: the provision, allocation, and deployment of capital. A fundamental job of financial regulation should be to correct failures that impair the ability of firms and markets to perform these economic functions. That necessarily includes protecting against systemic risk-the risk that the financial system will lose its ability to operate as a network within which its underlying economic functions can be conducted.

The Article also systematically examines how to design and implement financial regulation to protect these functions. This "functional" approach to regulation is not necessarily intended to replace existing approaches. Its primary purpose, rather, is to provide a set of regulatory ordering principles with which real-world financial regulation can be compared, whatever the existing financial architecture. That, in turn, could help to inform the uses and limits of regulatory tools and also could provide perspective on deciding between competing regulatory objectives and reduce the potential for regulatory arbitrage. The result should be a financial system that is more resilient than at present, with components that function more efficiently.

278. See supra notes $113-36$ and accompanying text. For example, the tools include restrictive credit and credit-growth ceilings to protect against assetprice bubbles that could ultimately result in economic downturns; but because economic growth is strongly tied to the availability of credit, these ceilings could cause a future economy to contract. 